\title{
Minimal Technologies Application Project, Hohenfels Training Area, Germany: Final Report
}

by S.D. Zellmer, R.R. Hinchman, D.O. Johnson, W.D. Severinghaus, " and J.J. Breri**

Reclamation Engineering and Geosciences Section, Energy Systems Division, Argonne National Laboratory, 9700 South Cass Avenue, Argonne, Illinois 60439

December 1991

Work sponsored by United States Army Corps of Engineers,

Construction Engineering Research Laboratories, Environmental Division,

Champaign, Illinois

"Severinghaus is affiliated with U.S. Army Corps of Engineers, Construction Engineering Research Laboratories, Environmental Division, and Brent with Environmental Management Office, Directorate of Engineering and Housing, Headquarters, 282nd Base Support Battalion, Hohenfels, U.S. Army.

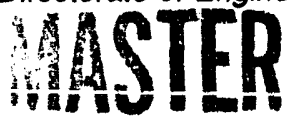




\section{Contents}

Acknowledgments............................................................. v

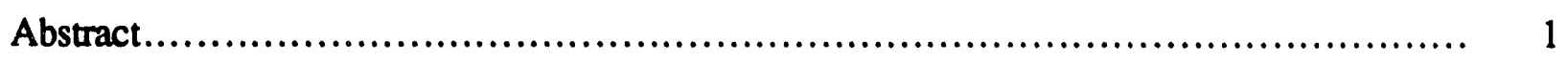

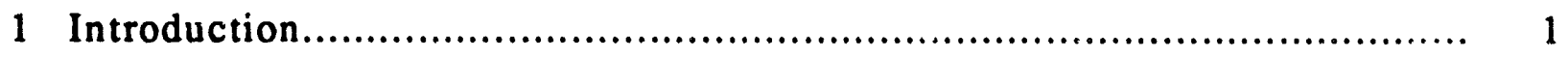

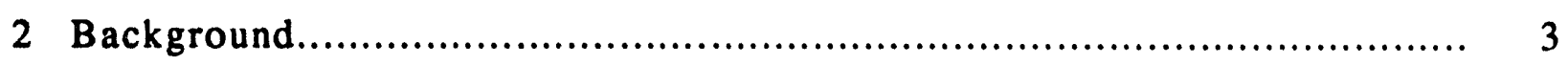

2.1 Hohenfels Training Area ..................................................... 3

2.2 Range 8C Rehabilitation Demonstration Project.................................... 5

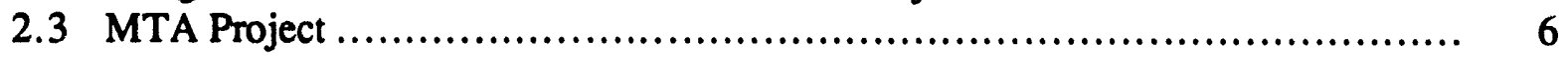

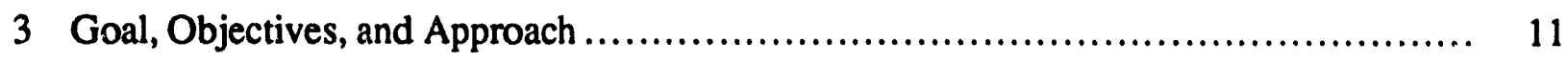

4 Methods.................................................................... 12

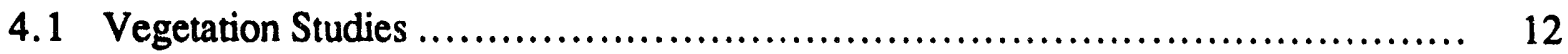

4.2 Cost Analysis ........................................................... 14

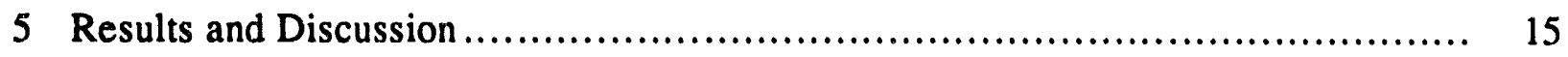

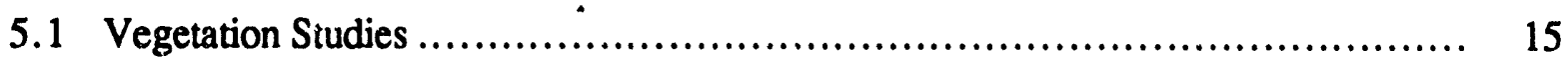

5.2 Cost Analysis ........................................................... 22

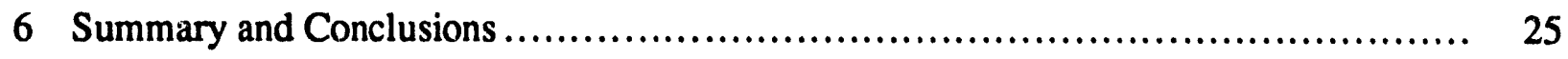

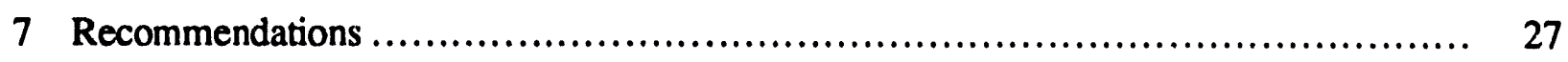

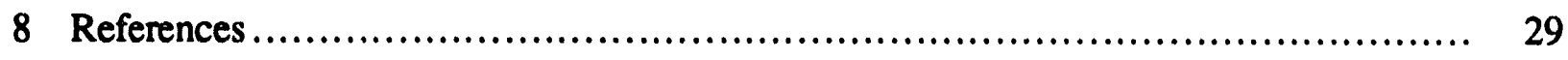

Figures

1 Location of Hohenfels Training Area in Germany ............................... 4

2 Location of the Project Site at Hohenfels Training Area................................... 7

3 Schematic of the Treatments as Implemented at the Project Site............................. 8

4 Collection of Ground Cover Data by the Point-Intercept Method Using the PointFrame at the Project Site . 


\section{Tables}

1 Seed Mixture and Seeding Rate Used at the Project Site ............................... 9

2 Mean Percent Cover of All Transects by Collection Date and Amendment Option ......... 17

3 Mean Percent Cover of All Transects by Collection Date and Closure Period................ 18

4 Mean Percent Cover of Undamaged Transects by Collection Date and Amendment Option ............................................................................. 20

5 Mean Percent Cover of Undamaged Transects by Collection Date and Closure Period.... 21

6 Cost of Materials and Operations for Implementation of Amendments at the

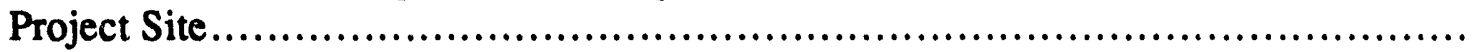




\section{Acknowledgments}

The monitoring effort for the Minimal Technologies Application (MTA) project at Hohenfels Training Area (HTA) in Germany was possible only because of the contributions and cooperation of a number of individuals and organizations. Colonel Gunther Seibert, Commander of HTA, personally supported the Range $8 \mathrm{C}$ project and the MTA project, and several other new environmental improvement and awareness programs were initiated at HTA under his command. Special thanks and recognition are extended to him and his staff.

Major Edward Tucker and his staff at the Directorate of Engineering and Housing (DEH), HTA, supported the project by providing the materials and labor necessary to close the site during the study. Members of the Environmental Management Office of DEH assisted in the collection of ground cover data during the monitoring effort and often provided transportation for the ANL staff. The day-to-day support and services provided by the entire DEH staff are greatly appreciated.

The U.S. Army Corps of Engineers Construction Engineering Research Laboratories (USACERL) is gratefully acknowledged for providing the necessary funding for both the implementation and monitoring phases of the project.

Finally, special thanks and appreciation are extended to Barbara Sullivan for her assistance and patience throughout the entire MTA project. 


\title{
Minimal Technologies Application Project, Hohenfels Training Area, Germany: Final Report
}

\author{
by \\ S.D. Zellmer, R.R. Hinchman, D.O. Johnson, \\ W.D. Severinghaus, and J.J. Brent
}

\begin{abstract}
At the U.S. Army Hohenfels Training Area in Germany, more than 30 years of continuous and intensive tactical training has caused extensive environmental damage because of the loss of vegetative cover and accelerated soil erosion. A project was conducted to evaluate the cost-effectiveness and relative benefits of various revegetation procedures. These procedures involved amendment and seedbed preparation options that were combined with three different durations of site closure. The point-intercept method was used to measure the types and amounts of vegetation established and changes in the vegetative community. Over three growing seasons, applications of fertilizer and seed increased the percent grass, legume, and total vegetative cover. The duration of site closure had no influence on the types or amounts of ground cover established. Materials made up only $10 \%$ of the total cost of the fertilization and seeding operations. The results of the research indicate that less expensive methods of amendment application should be evaluated. The data also show that site closure is not practical, economical, or necessary. The results of this project suggest that a regular maintenance program consisting of seeding and fertilization is required to maintain adequate vegetative cover and control erosion on tactical training areas.
\end{abstract}

\section{Introduction}

Approximately one-third of the U.S. Army is deployed in Europe, but only about $87,900 \mathrm{ha}(217,200$ acre $)$ of land is available in Europe for housing and training Army personnel. For comparison, the available training area in Europe is approximately equal to that of Fort Hood, Texas. The majority of U.S. Army Europe (USAREUR) units are stationed in Germany, and they must maintain tactical combat readiness because of their strategic location. Tactical training in the densely populated and highly industrialized German countryside is expensive; the cost of compensation for maneuver damage is high and increases each year. The numbers and sizes of existing tactical training areas are limited because of the intensive land use. New and improved weapon systems have changed tactical training doctrines, requiring combat units to operate over larger sectors of the landscape and engage targets at greater ranges than in the past. Also, 
U.S. tactical training areas are often used by combat units of other countries in the North Atlantic Treaty Organization. All of these factors result in high training pressure on U.S. military training areas in Germany. The overuse of existing training areas has damaged or destroyed the vegetative ground cover at many locations. The loss of plant cover results in accelerated soil erosion, which damages natural resources, results in safety hazards, and diminishes training realism.

The most cost-effective method of stabilizing soil and controlling erosion is to establish a self-sustaining vegetative ground cover. Living plants and plant litter intercept raindrops, thereby reducing the impact energy of the raindrops and the potential for sheet erosion. Plant roots bind soil particles and increase soil porosity, thereby reducing the volume and velocity of runoff. Vegetative cover prevents overland runoff flows from converging into a single stream and diminishes the potential for the development of rills. Without protective plant cover, rills become gullies that increase in size with each runoff event, and gullies in training areas are a major safety hazard to personnel and vehicles. Sheet, rill, and gully erosion produce sediments that are carried into streams and onto adjacent areas. The appearance of a barren and eroded landscape at U.S. military training areas leads to concerns among local residents and officials regarding the existence of the training area. Establishing and maintaining vegetative ground cover on a training area is the most cost-effective method of providing combat units with an environmentally sound, safe, and realistic training habitat.

The Minimal Technologies Applications (MTA) project was initiated in 1987 at the Hohenfesls Training Area (HTA) in Germany to evaluate options for establishing vegetative ground cover on tactical training areas at minimal cost and disruption to training activities. The project was designed so that a variety of amendments and seedbed preparation options, in combination with closure periods of various durations, could be evaluated for their effectiveness in establishing vegetation for erosion control. The amendments and seedbed preparation options were designed to represent a wide range of costs for labor and equipment use. Closure periods ranged from about two weeks (with minimal disruption to training activities) to one year (so that the vegetation had one growing season for root development and establishment). The amounts and types of ground cover were measured on replicate transects in each treatment area during spring, summer, and fall for almost three growing seasons after implementation of the treatments. The study was designed to provide basic information on the minimal amendments, seedbed preparation operations (cost), and site closure periods (time) required to establish acceptable vegetative cover for adequate erosion control on tactical training areas. 


\section{Background}

The Environmental Division of the U.S. Army Corps of Engineers Construction Engineering Research Laboratories (USACERL), located in Champaign, Illinois, has been given the responsibility of developing and implementing the Integrated Training Area Management (ITAM) program. The ITAM program is a systematic land-management program designed to develop the processes and tools necessary to enhance resource conservation and improve the training missions at U.S. Army installations. The major thrusts of the ITAM program are as follows: (1) standardization of methods for assessing environmental conditions and land-use capabilities; (2) integration of training needs with the training mission and environmental concerns; (3) development of programs to educate military personnel in environmental awareness and resource conservation; (4) implementation of computer-based land-management decision and scheduling systems for resource data analysis; (5) development of cost-effective rehabilitation and maintenance technologies for training areas; and (6) development of strategies for the management of threatened and endangered species.

The initial ITAM effort in Europe was started in early 1986 with the Range 8C Rehabilitation Demonstration Project at the Hohenfels Training Area (HTA) in Germany. Hohenfels Training Area is the U.S. Combat Maneuver Center in Europe. Representatives from USACERL requested that the Reclamation Engineering and Geosciences Section (RE\&G) of the Energy Systems Division at Argonne National Laboratory (ANL) assist in the development of costeffective rehabilitation and maintenance technologies for training areas (element 5 of the ITAM program). The Reclamation Engineering and Geosciences Section at ANL was selected because it has more than 15 years of experience in applied land-reclamation research and because it is taking part in a similar USACERL/ANL project under way at Fort Carson, Colorado.

\subsection{Hohenfels Training Area}

Hohenfels Training Area is operated by the Seventh Army Training Command, headquartered in Grafenwöhr, Germany. The HTA is located amid the forest and farmland in the Oberpfalz region of Bavaria, approximately $120 \mathrm{~km}(75 \mathrm{mi})$ north of Munich and about halfway between Nuremberg and Regensburg (Figure 1). In 1938, the German A:med Forces (Wehrmacht) established HTA as a military area for training German forces and testing weapons systems. During World War II, HTA was used as a prisoner-of-war camp. The American Army occupied HTA in April 1945, and parts of the original installation were used as a displaced-person camp until 1949 (Griesbach 1988). The U.S. Army requisitioned HTA for use as a tactical training area in 1951 and enlarged it to its current area of about 16,200 ha (40,000 acre) in 1952. The HTA is currently the largest maneuver training area available to the U.S. Army in Europe.

Hohenfels Training Area and the Oberpfalz region of Bavaria have a humid mesothermal climate. Winters are moderately cold; January temperatures average about $0^{\circ} \mathrm{C}\left(32^{\circ} \mathrm{F}\right)$, but the temperature may fall to $-25^{\circ} \mathrm{C}\left(-13^{\circ} \mathrm{F}\right)$ for a few days. Summers have warm days and cool nights, 


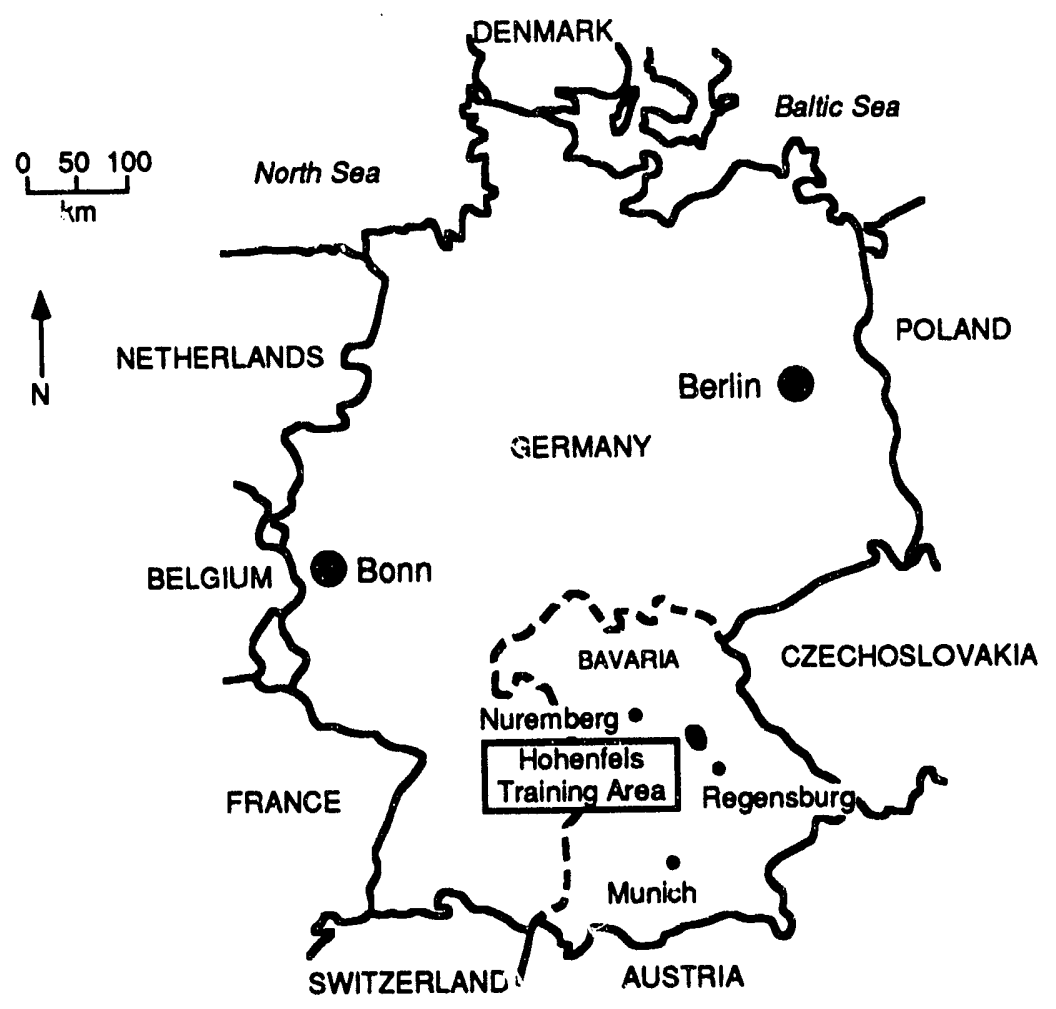

FIGURE 1 Location of Hohentis Training Area in Germany

and temperatures average $13^{\circ} \mathrm{C}\left(55^{\circ} \mathrm{F}\right)$ during July, the warmest month. Precipitation, mainly rain, is fairly evenly distributed throughout the year and averages about $960 \mathrm{~mm}$ (37.8 in.). Snowfall can occur from late October through early April. During the winter, soils are not normally frozen, and snow cover is limited to a few days because daytime temperatures are above freezing.

Hohenfels Training Area is slightly higher in elevation than the adjacent landscape, with elevations ranging from about $650 \mathrm{~m}(2,050 \mathrm{ft})$ at the highest hilltop near the western boundary to approximately $350 \mathrm{~m}(1,150 \mathrm{ft})$ at the lowest point in the southeastern corner. The physiography of the training area is rolling hills alternating with wide, concave valleys. Valley floors usually have moderate slopes of less than $10 \%$ and are less than $100 \mathrm{~m}(328 \mathrm{ft})$ below the adjacent ridge tops. Upper slopes near the ridge tops are often very steep, with slopes of more than $45 \%$, while the lower slopes adjacent to the valley floors are moderately steep to steep, ranging from 10 to $30 \%$. The geology and native soils with vegetative cover at HTA have moderate to high infiltration rates. Only two perennial streams originate in HTA, the Kesselgraben (in the southeastern corner) and the Forellenbach (starting near the cantonment area). During periods of rainfall or snow melt, intermittent streams also flow in most valleys. Because HTA has a slightly higher elevation than the surrounding countryside, all drainage flows off HTA and into three rivers that are the general boundaries on three sides of HTA: the Lauterach on the north, the Vils on the east, and the Forellenbach on ine southeast. 
The area surrounding HTA is about equally divided between forest and farmland. Valleys and gentle side slopes are in meadows harvested for forage or used for the production of small grains, rape, and com fed as forage. The steeper slopes and many ridge tops are in coriferous and mixed forests. The land use of HTA, before it was converted to a training area, was similar to that of the adjacent countryside (Griesbach 1988), and the steeper slopes and ridge tops have remained in coniferous and mixed forests that are managed by the German Federal Forest Service. Meadows have remained open areas because of training activities and a sheep grazing program. Fields that were cultivated have reverted to abandoned field communities of grasses and legumes adapted to the region. Although the plant communities in the valleys and upland meadows contain a mixture of grass and legume species, many large areas are disturbed and barren, lacking adequate vegetative ground cover to control erosion and runoff.

For almost 40 years, the U.S. Army has used HTA for tactical training, which requires that tanks, armored personnel carriers, and support vehicles be deployed throughout the training area. Continued military traffic in the valleys and on their side slopes has produced numerous trails and areas devoid of vegetation that are subject to accelerated erosion. Tactical use of the forest edge for vehicles has destroyed virtually all of the ground cover in that area. Vehicles maneuvering for attack or defense positions along the forest edge have damaged trees and destroyed the forest understory. The construction of tank ditches and defilade positions darnages or destroys vegetative ground cover and therefore exposes the soil and increases the rate of soil erosion. At strategic locations on the landscape, the soil has been disturbed so often that natural revegetation does not occur; soil erosion is rampant in these areas. As a result of these activities, the landscape has lost all semblance of the adjacent countryside and lacks training realism. Because erosion and runoff are uncontrolled, gullies have developed at many locations on the training area, resulting in safety hazards to troops and equipment. Sediments are carried by runoff to streams outside HTA. Local residents find the degradation of water quality in streams adjacent to HTA and the disheveled appearance of the landscape offensive. These problems are of serious concern to U.S. Army representatives.

\subsection{Range 8C Rehabilitation Demonstration Project}

Argonne participation in the ITAM program began with the Range $8 \mathrm{C}$ Rehabilitation Demonstration Project, which began in 1986. This project was designed to demonstrate that tactical training areas could be rehabilitated to conserve natural resources, diminish safety hazards, and improve training realism by reestablishing vegetative ground cover and implementing erosion control practices. Range $8 \mathrm{C}$ was selected as the site for the rehabilitation demonstration project because site conditions and training damage were typical of HTA. During the early summer of 1986, the conditions at Range $8 \mathrm{C}$ were assessed. Information was collected on the types and amounts of existing vegetation, types and degrees of erosion, topography, and soil characteristics. This site-specific information was combined with various reclamation options to develop 11 rehabilitation prescriptions for specific subareas of Range 8C. Seven of the prescriptions involved revegetation options that consisted of various combinations of fertilizers, seed mixtures, and seedbed preparation methods. The remaining prescriptions included four erosion-control practices that included a graded terrace and grassed waterway system and three types of riprap 
water-flow-control structures. Prescriptions were implemented by a local contractor in the fall of 1986, and the site was closed to military use for one year. A detailed description of the development and application of the prescriptions at Range $8 \mathrm{C}$ is available from USACERL (Zellmer et al. 1987).

The cost of each prescription was determined on the basis of the materials, labor, and equipment use required during implementation. Immediately after implementation of the prescriptions, a site monitoring program was initiated to determine the effectiveness of each prescription. The prescription areas were monitored through the spring of 1990 to determine the extent to which renewed military use affected each prescription. The amounts and types of plant cover on revegetation prescription areas were measured each spring, summer, and fall. The effectiveness and the durability of the erosion control structures were assessed on the basis of field observations made during the monitoring of vegetation. The cost of each prescription was compared with its effectiveness in reestablishing vegetation and/or controlling erosion. A detailed description of the results of the monitoring effort is available from USACERL (Zellmer et al. 1991).

The goal of the Range $8 \mathrm{C}$ project was to develop and demonstrate that training areas in Germany could be revegetated and rehabilitated. During the spring of 1987, preliminary results of the project indicated that acceptable plant cover could be established by implementing revegetation prescriptions, but the cost of seedbed preparation operations (e.g., leveling, ripping, rototilling) and some seeding methods (drilling and hydroseeding) was considered high. Other data from Range $8 \mathrm{C}$ indicated that broadcast seeding without extensive seedbed preparation could establish adequate ground cover at a much lower cost. Field observations at Range $8 \mathrm{C}$ also indicated that it was not practical or possible to completely exclude military or other traffic from the site after implementation of revegetation operations. These observations indicated the need to develop and evaluate procedures that minimize the cost and the duration of site closure while adequate vegetative ground cover becomes established for erosion control. Therefore, planring for the MTA project began during the spring of 1987 .

\subsection{MTA Project}

The major factors considered during site selection for the MTA project were previous and expected military use of the area and the size of the site. The relative uniformity of the soils, vegetative community, and topography of the site were also major factors that were considered. Continued and future military activities in the area were necessary to evaluate the influence of site closure periods, and the site had to be large enough to accommodate several treatments. Major differences in soil properties, existing ground cover, or topography would bias the results of revegetation efforts. With the assistance of USACERL and DEH staff at HTA, several potential project sites were located, inspected, and ranked according to the selection criteria.

The site selected for the MTA project was a 13.5-ha (33-acre) site near the ruins of the village of Raversdorf in a heavily used valley at HTA (Figure 2). The site was located in a valley 


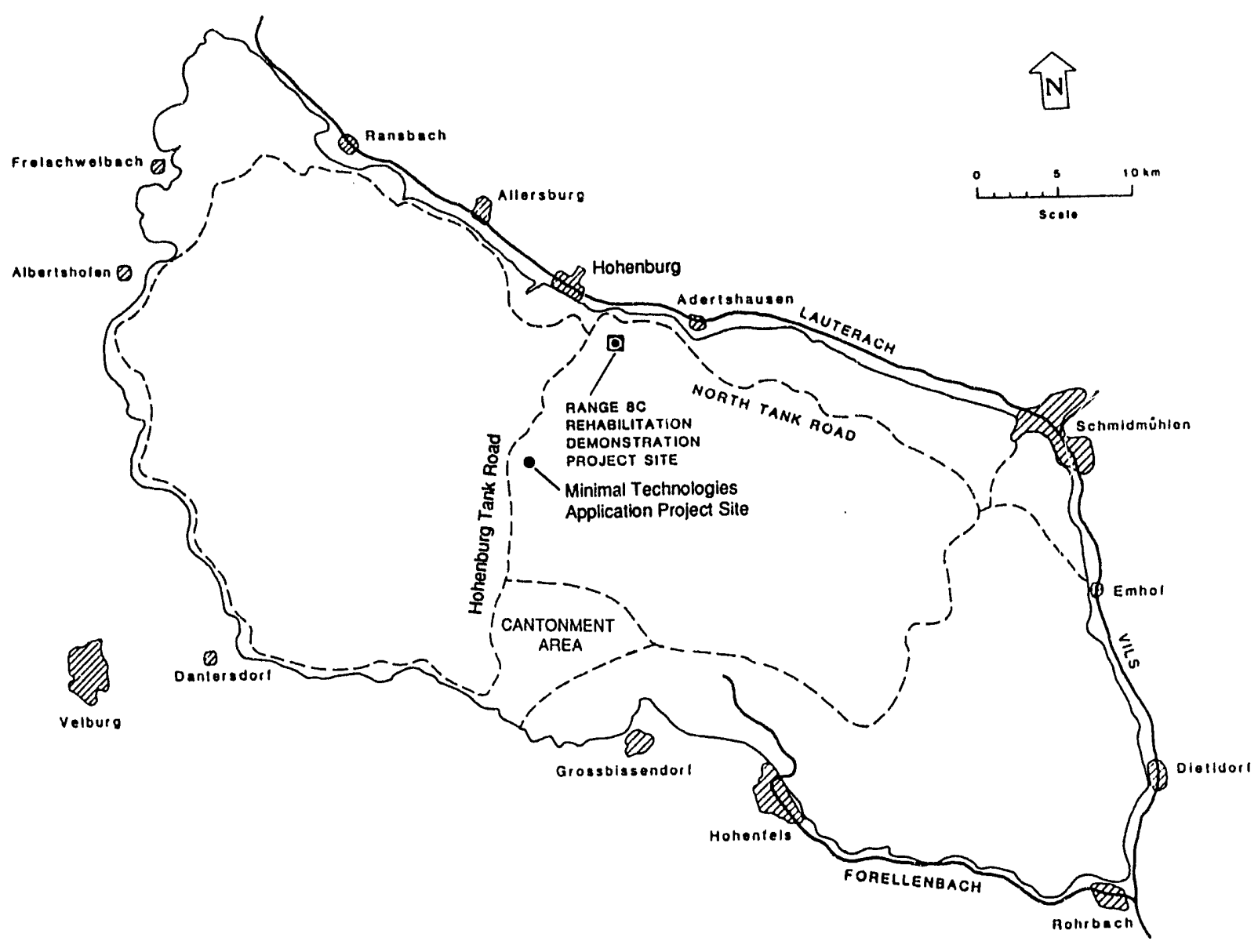

FIGURE 2 Location of the Project Site at Hohenfels Training Area

that was more than $500 \mathrm{~m}$ (1640 ft) wide and extended from the Hohenburg Tank Road to the east for several kilometers. The width of the valley provided ample space for the study site, and military training activities were expected to continue in the area. An inventory of the site was conducted, and surface-soil samples were collected for analyses. The existing ground cover consisted of scattered forbs and grasses, with numerous tank trails and barren areas caused by tank ditch excavations. The amount of ground cover was generally low $(<50 \%)$ and about the same throughout the site. The results of soil sample analyses indicated that the soil at the site was also relatively uniform and low in phosphorus. The major disadvantage of the site was the numerous small tree plots throughout the area.

A matrix plot design was selected to provide a framework for the evaluation of 12 treatments consisting of four amendn'ent and seedbed preparation options that were combined with three site-closure periods. The first and least expensive amendment option was to broadcast fertilizer and seed without the preparation of a seedbed. The second option was to broadcast fertilizer and seed and then to harrow the soil. (The soil was harrowed to provide sites on compacted tank trails in which seeds could become established.) The third option involved 
preparing the seedbed by ripping and rototiliing, broadcasting fiertilizer and seed, and harrowing. This combination of operations was similar to a successful prescription implemented at Range $8 \mathrm{C}$, but the cost of ripping and rototilling was considered high. For the final option, no amendments were used so that the natural revegetation process could be evaluated (without the direct cost for materials or labor). This final option was a control that was used to determine the relative effectiveness of the three other amendment and seedbed preparation options.

The durations of the three closure periods were about two weeks, approximately two months, and one year. The two-week closure coincided with the normal training cycle of a unit at HTA. The two-week period was assumed to be too short to benefit the development of vegetation, but it was included to minimize the disruption to training activities. During the two-month closure, it was expected that vegetation would begin to become established and grow before military use of the site. The one-year closure provided one full growing season for the development of roots and establishment of ground cover. One year was considered the maximum period a site could be closed and was the same duration as that being tested at Range $8 \mathrm{C}$. The combination of the four amendment and seedbed preparation options with the three closure periods provided 12 different treatments in the matrix design.

The matrix plot design was a quadrang'e, with the four amendment and seedbed preparation options perpendicular to the valley side $\quad z r e 3)$. The areas for the closure periods were arral. zed in rows that ran along the valley floor. The area for the briefest closure period was near the center of the valley and away from the: tree line, the area for the intermediate closure period

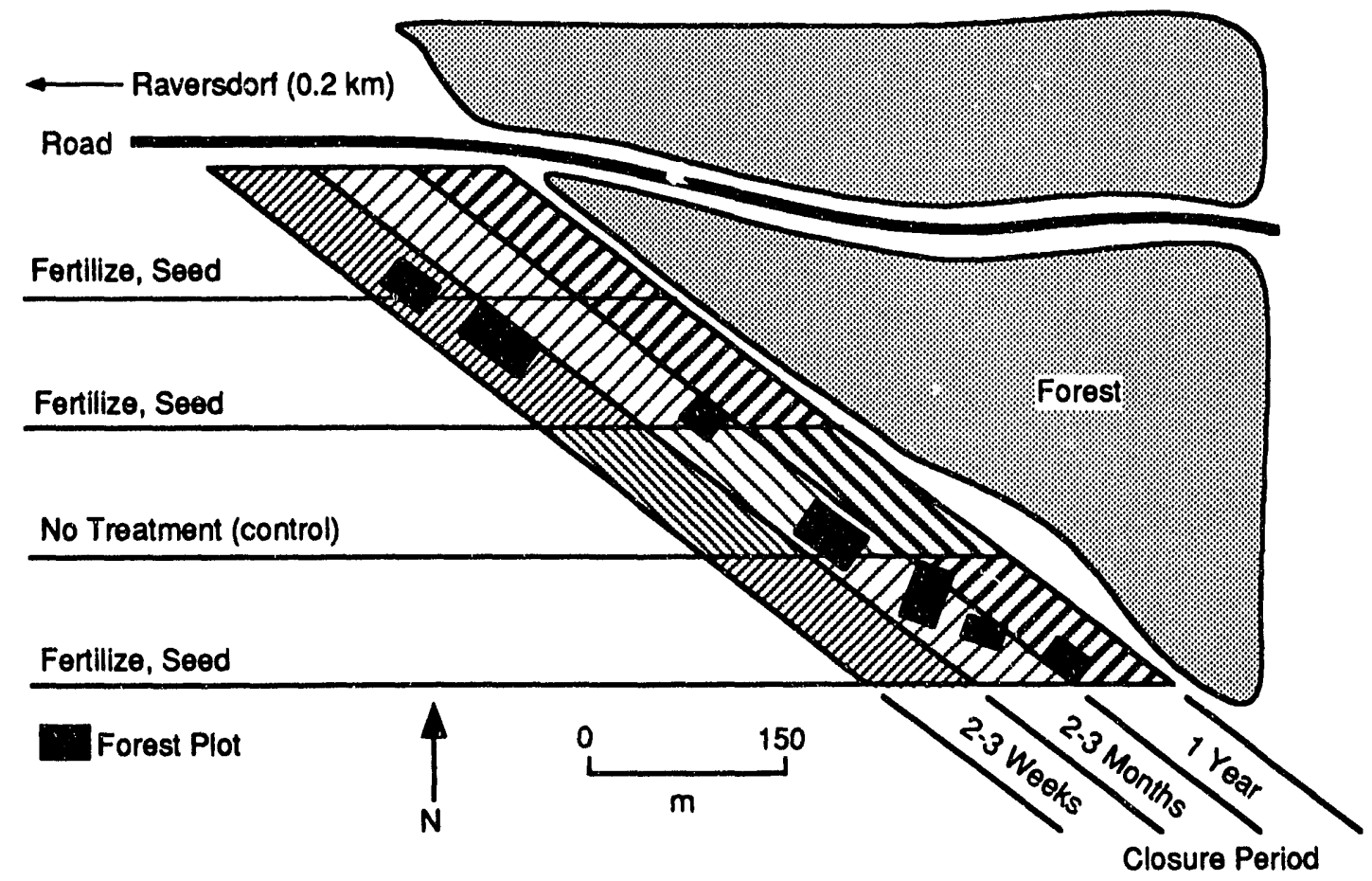

FIGURE 3 Schematic of the Treatments as Implemented at the Project Site 
was in the center, and the area for the longest closure period was adjacent to the valley side-slope and tree line. A triple strand of concertina wire enclosed the entire site to prevent military traffic from entering the study area at the start of the study. The concertina wire was moved across the site at the end of a closure period, thereby allowing military traffic to travel on the newly opened treatments. Amendments used in the study consisted of a single rate of fertilization and a common seed mixture and seeding rate because different amounts or types of amendments would greatly increase the number of treatments. The phosphorus and other nutrient: that were needed to aid in the establishment of vegetation were supplied by an application of $\mathrm{N}, \mathrm{P}_{2} \mathrm{O}_{5}$, and $\mathrm{K}_{2} \mathrm{O}$, each at a rate of $25 \mathrm{~kg} \mathrm{ha}^{-1}(23.2 \mathrm{lb}$ acre-1). The seed mixture used was the saine as that used in the meadow at Range 8C (Table 1 ).

Arrangements were made with the Directorate of Engineering a'id Housing at HTA to provide the concertina wire and labor to install and move the wire during the study. Specifications for the application of fertilizer, the preparation of seedbed options, and the application of seed were prepared, translated into Germar, and submitted to local contractors for bids. The contract was awarded to the lowest bidder, and implementation of the treatments was scheduled to begin June 8, $198^{\circ}$

Above-average rainfall during May and the first three weeks of June saturated the soils at the site, and runoff collected in the numerous deep ruts at the site, forming small ponds. Because of the lack of ground cover, the rain caused the surface soil to become sticky mud. These conditions prevented the contractor from beginning the work until the last week of June. Attempts were made to prepare and harrow the seedbed, but the rutted surface and standing water prevented the contractor from performing these operations as specified. After four days of unsuccessful

TABLE 1 Seed Mixture and Seeding Rate Used at the Project Site

\begin{tabular}{|c|c|c|c|c|}
\hline \multirow[b]{2}{*}{ Botanical name } & \multirow[b]{2}{*}{ Common name } & \multirow[b]{2}{*}{ Soeds $\mathrm{g}^{-1}$} & \multicolumn{2}{|c|}{ Soeding Rate ${ }^{\circ}$} \\
\hline & & & $\mathrm{kg} \mathrm{ha-1}$ & Seeds $m^{-2}$ \\
\hline Agropyron repens & Quackgrass & 243 & 7.0 & 170 \\
\hline Bromus inermis & Smooth bromegrass & 300 & 6.0 & 180 \\
\hline Dactylis glomerata & Orchardgrass & 1,442 & 1.5 & 216 \\
\hline Festuca rubra rubra & Creeping red fescue & 1,356 & 1.5 & 203 \\
\hline Phalaris arundinacea & Reed canarygrass & 1,175 & 1.5 & 176 \\
\hline Lotus corniculatus & Birdsfoot trefoil & 827 & 5.0 & 413 \\
\hline Trifolium repens & White clover & 1.764 & 3.0 & 529 \\
\hline Scale cereale & Cereal rye & 40 & 50.0 & 200 \\
\hline Total & & & 75.5 & 2,087 \\
\hline
\end{tabular}

"Pugre live seed. 
efforts, the contractor gave up and removed his tillage equipment from the site. The broadcast application of the fertilizer and seed mixture was completed at the prescribed rates, but the process was slowed by the wet and rutted conditions of the site.

Because the contractor failed to perform various seedbed preparation operations as specified, the design of the study had to be modified. Four amendment and seedbed preparation options had been planned: (1) fertilization and seeding; (2) fertilization, seeding, and harrowing; (3) fertilization, complete seedbed preparation, seeding, and harrowing; and (4) no treatment (study area with natural revegetation). In effect, only the amendment options were implemented (application of fertilizer and seed; natural revegetation), but three closure periods remained in the project design. The final design of the study, consisting of two amendment options and $t$ closure periods, is shown in Figure 3. 


\section{Goal, Objectives, and Approach}

The goal of the Mintimal Technologies Application Project was to develop and evaluate revegetation procedure amendment and seedbed preparation options combined with closure periods) to establish adequate vegetative ground cover for erosion control at minimal cost and disruption to training activities. The objectives of the project were to (1) determine if amendments and seedbed preparation options affect the types and amounts of vegetation established, (2) evaluate the influence of closure duration on the types and amounts of vegetation established, (3) compare the cost of amendments and seedbed preparation options with the types and amounts of vegetation established, and (4) for rulate recommendations for future revegetation efforts on tactical training areas.

The MTA project had two phases. The initial phase (planning and installation) involved the development of a project work plar, selection of a study site, preparation of specifications for the rehabilitation contractor, and application of the treatments at the study site. Because of saturated soil conditions and standing water on the site during the application of treatments, several of the seedbed preparation operations to be tested were eliminated from the experimental plan. The final design of the study consisted of tivo amendment options and three closure periods. The cost of the amendments (fertilizer and seed mix ture) and the cost of applying the amendments were determined on the basis of the adjusted price paid to the contractor. The initial phase of the project was completed with the implementation of the treatments during late June 1987; a detailed description of the initial planning and imp!'mentation phase is provided in Zellmer et al. (1989).

The second phase of the project consisted of measuring the types and amounts of vegetation established by the treatments tested at the site. Replicate transects were established in each of the 12 original treatment areas at the site, and vegetative ground cover data were collected each spring, summer, and fall through the spring of 1990 . Ground cover data were collected each season to evaluate the effectiveness of the amendment options and closure periods after renewed military use of the site. Throughout the monitoring phase or the project, field observations were made and a record of site conditions was maintained by photographs and videotape. This report describes the monitoring effort, summarizes the data collected, provides an interpretation of those data, and gives recommendations for future revegetation efforts on tactical training areas. 


\section{Methods}

\subsection{Vegetation Studies}

Initial measurements of ground cover were made during late June 1987, before the treatments were applied. At that time, 36 permanent transects for monitoring ground cover were established in the 12 original treatment areas. Three $10-\mathrm{m}$ transects were established in each treatment area and used as replicates. All transects were located on tank trails or in other areas devoid of vegetation. These barren locations were selected because the goal was to determine the types and amounts of ground cover established by the treatments, not to monitor the changes in the type and amount of existing vegetation on the site. To ensure that subsequent observations could be made from the same locations during the monitoring phase of the project, transect locations were referenced to landmarks on and near the site. Additional cover measurements were taken on the 36 transects each spring, summer, and fall through the spring of 1990, when the monitoring phase of the project was discontinued.

The point-intercept method (Chambers and Brown 1983) was used to measure the amounts of exposed soil, litter, and types of vegetation established. Each transect was $10 \mathrm{~m}(32.8 \mathrm{ft})$ in length, and the types and amounts of ground cover were determined at $1-\mathrm{m}(3.28-\mathrm{ft})$ intervals by using a point-frame with 10 pins (points), as shown in Figure 4. Exposed soil, litter, or the types of vegetation (i.e., grass, legume, forb) were recorded under each pin or observation point. The 10 frame settings of the 10-pin frame provided 100 observations from each transect, and the three transects in each treatment area were used as replicates for statistical calculations. During collection of the data, only the initial point of contact was recorded. Data were recorded by categories exposed soil, litter, grasses, forbs, legumes, and cereal rye. In addition to the ground cover data, the number of point-frame settings on each transect damaged by recent obvious vehicle traffic was recorded.

A computer program was developed at ANL to process and summarize field data as the percent cover in the six categories (i.e., exposed soil, litter, grasses, forbs, legumes, and cereal rye) on each transect. Because 100 observations were made on each transect, the number of pin contacts in each category equaled the percent cover in that category. The percent total vegetative cover category for a transect was calculated by summing the percent grass, forb, legume, and rye values. The percent total ground cover could be calculated by subtracting the percent exposed soil values from 100 or by adding percent litter to total percent vegetative cover. Percent total ground cover values were not calculated, sumniarized, or analyzed because the percent exposed soil values are the inverse of the percent total ground cover values. The percent damage on a transect was calculated by multiplying the number of damaged point-frame settings by 10 because 10 frame settings were made on each transect. The mean of the percent damage on the three transects in a treatment area was considered the average damage for the treatment area.

A general linear model (GLM) procedure of the SAS programs (Ray 1982) was used to statistically compare the seven categories of the cover data from the two amendment options and 


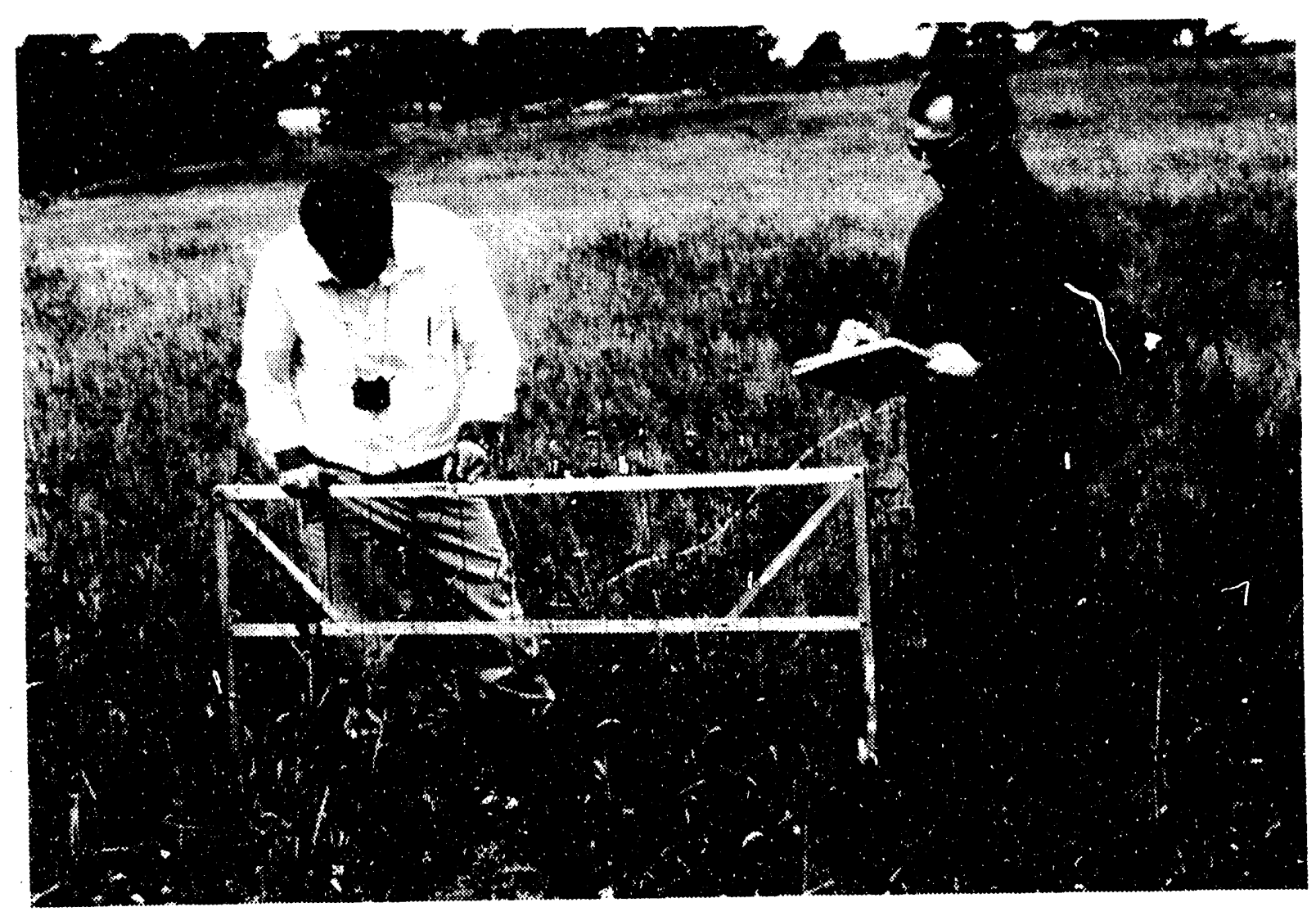

FIGURE 4 Collection of Ground Cover Dali is the Point-Intercept Method Using the PointFrame at the Project Site

three closure periods for each of the eight collection dates. Two separate sets of analyses were performed - one set included data from all transects to determine differences among category treatment, and the second set included only data from transects where recent damage was not observed. Analyses of variance of values expressed as percentages were not possible because percentages violate the assumption of variance homogeneity required for regression analysis. One solution to the variance homogeneity problem is a data transformation, and a normal transformation for percent values is the arc sine of the square root of the percent value expressed as a decimal fraction. * This transformation tends to stabilize the variance and normalize the percent values. Another statistical analysis problem was that of maintaining the 0.05 level of significance while making multiple t-test comparisons (the mean from each treatment versus the means of all the other treatments). The problem of multiple comparisons of means was resolved by using Sidak's pairwise $t$ tests (Miller 1966). Sidak's method performs pairwise $t$ tests on differences between

\footnotetext{
- Carnes, B.A., 1984, personal communication, Biostatistician, Biological and Medical Research Division, Argonne National Laboratory, Argonne, Ill.
} 
means, with levels adjusted according to Sidak's inequality for all means. This procedure maintains a 0.05 level of significance for comparisons among multiple means.*

\subsection{Cost Analysis}

The amount of economic data collected was limited because the rehabilitation contras,tor applied only two of the amendments - broadcasting the fertilizer and applying the seed mixture. The cost of these operations, along with the cost of the fertilizer and seed mixture, was derived from the revised price paid to the contractor. These costs included the contractor costs for overhead, supervisory personnel, German value-added tax, mobilization and demobilization of equipment, and profit, as well as the cost of the materials, labor, and equipment. All costs were for the actual area treated in 1987 real dollars; no adjustment was made for future value. Cost data were combined with the results of the ground cover data collected during the monitoring phase of the project so that the practicality of the fertilization and seeding operations could be determined. The value of the concertina wire and the labor cost for installing, moving, and removing the concertina wire were not calculated because the wire and labor were provided by DEH at HTA.

* Carnes, B.A., 1984, personal communication. 


\section{Results and Discussion}

\subsection{Vegstation Studies}

Two objectives of the MTA project were to (1) determine the types and amourits of vegetative ground cover establisined by the amendments and seedbed preparation options and (2) evaluate the influence of duration of site closure on the types and amounts of vegetation established. These objectives were selected because the establishment and maintenance of a vegetative ground-cover community with a high proportion of grass is an important factor in controlling erosion and runoff on training areas. The amounts of ground cover (vegetative cover plus litter) and exposed soil have been shown to be highly correlated with erosion rates and soil stability (Hoffman et al. 1983; Meeuwig 1970). All types of ve stative cover, however, do not provide equal erosion protection and soil stabilization. Grasses are usually considered to be more effective than most forbs in controlling erosion (Wischmeier and Smith 1978) because grasses have multiple stems and fibrous root systems that bind and hold soil particles. Forbs usualiy have a single stem and often have a shallow or taproot system that does not bind the soil as effectively as grass roots do. Dormant grasses tend to remain intact and rooted in the soil, whereas the aboveground parts of dead forbs tend to break up into loose, unattached litter at the end of the. growing season. The monitoring effort was designed to determine both the types and amounis of vegetative cover that became established and had survived under the six treatments tested at the site.

To determine the types and amounts of vegetation that became established and had survived under each of the six treatments tested, ground cover data were collected at regular time intervals by using the point-intercept method. Only the initial contact of the pin with the ground was recorded, a technique that provides an accurate representation of the relative amounts of exposed soil, litter, and type of vegetation. However, recording only the initial contact of the pin with the ground can introduce a b.r s in o the species composition data because the initial contact of the pin is usually with the taller species. As a result, the composition of the shorter species is underestimated. The initial contact of the pin does, however, indicate if raindrops would be intercepted by the litter or vegetation, a primary factor influencing erosion rates.

The data collected during the closure period were to indicate differences in the types and amounts of vegetation established as a result of the application of different seedbed preparation options. But because the contractor failed to perform all the amendment and seedbed preparation options as specified, the number comparisons that could be made were limited. In effect, only two amendment options were tested: (1) broadcast application of fertilizer and the seed mixture and (2) no amendments with natural revegetation. In addition, military traffic occurred on the portions of the site during the designated closure periods. On several occasions, someone cut the wire intended to exclude traffic from a designated closed area, and tanks and other vehicles drove through closed areas. This unauthorized traffic usually occurred on existing trails, and because many transects were located on these trails, vegetation was subjected to traffic during the designated closure periods. The traffic compromised the value of the information intended to be 
used to determine the influence of military traffic on vegetation establishment and survival. Unfavorable (but typical) weather during implementation of amendment and seedbed preparation options and unauthorized traffic are only two factors often hindering rehabilitation efforts on tactical training areas. These factors compromised the design and value of the MTA project, but even with these limitations, valuable information was obtained on procedures for the revegetation of military training areas.

Ideally, significant differences among category means of the different treatments at the MTA site would indicate the effectiveniess of each treatment option in establishing and promoting the survival of ground cover. Comparing the vegetation data gathered at one treatment location with data gathered during a previous collection at that location would indicate the rate and direction of change in the types and amounts of ground cover observed. The results of such a comparison would indicate the influence of military use on the vegetative community; unfortunately, unauthorized military traffic on the project site made these types of comparisons useless. Therefore, statistical analyses were limited to comparisons of ground cover data collected during each of the eight collection dates. The means of each ground cover category from the two option areas were compared so that the influence of amendment application could be determined. Other statistical analyses were conducted so that closure periods could be determined. These types of analyses were initially made by using the data from all ransects; after the initial analyses, only the data from undamaged transects were used.

The presence or absence of statistically significant differences may not always reflect actual differences among means from the areas that were treated or the areas that were closed to military traffic. If replicate (transect) values for a category are relatively uniform, a comparatively small numeric difference between the means of two areas can result in a significant statistical difference. These small numeric but statistically significant differences may not represent a meaningful difference with regard to the quality and quantity of the vegetative community. Conversely, large numeric differences between means may not be statistically significant because of large numeric differences among replicate (transect) values within the category. A major factor that caused large numeric differences between replicate (transect) values at the MTA site was the damage attributable to unauthorized military traffic. Traffic on transects was not uniform in an area, and the large differences in traffic patterns produced a high coefficient of variation, which eliminated statistically significant differences among areas. Even with these limitations, differences between treatment means and trends in the ground cover data did provide an indication of the differences among the option and closure areas tested.

Initial collections of ground cover data were made in June 1987, before the application of the options and initiation of closure periods. The data confirmed that all transects had nearly $100 \%$ exposed soil with little or no vegetation or litter present at the start of the study. Table 2 lists the mean coverage of the seven ground cover categories and the average percent damage for all transects by amendment option for the eight collection dates. Table 3 also provides the mean percent value of each ground cover category for all transects (means are grouped by closure periods for the eight collection dates). Statistically significant differences among means within each category and collection date are indicated. 
TABLE 2 Mean Percent Cover of All Transects by Collection Date and Amendment Option

\begin{tabular}{|c|c|c|c|c|c|c|c|c|c|}
\hline \multirow[b]{2}{*}{$\begin{array}{c}\text { Collection } \\
\text { Date }\end{array}$} & \multirow[b]{2}{*}{$\begin{array}{c}\text { Amendment } \\
\text { Option }\end{array}$} & \multicolumn{8}{|c|}{ Cover by Category $(\%)^{\dagger}$} \\
\hline & & Girass & Legume & Forb & Rye & $\begin{array}{c}\text { Total } \\
\text { Vegetation }\end{array}$ & Litter & $\begin{array}{l}\text { Exposed } \\
\text { Soil }\end{array}$ & Damage \\
\hline $6 / 1987$ & All\$ & 0.6 & 0 & 0.3 & 0 & 0.9 & 0 & 9.1 & 100.0 \\
\hline $9 / 1987$ & $\begin{array}{l}\text { F \& S } \\
\text { Control }\end{array}$ & $\begin{array}{l}13.4 \text { ałt } \\
11.0 \mathrm{a}\end{array}$ & $\begin{array}{l}5.6^{a} \\
0.9^{b}\end{array}$ & $\begin{array}{l}8.9^{a} \\
9.9^{a}\end{array}$ & $\begin{array}{l}6.0^{a} \\
0.1^{b}\end{array}$ & $\begin{array}{l}33.9^{a} \\
21.9^{a}\end{array}$ & $\begin{array}{l}1.2^{b} \\
1.3^{a}\end{array}$ & $\begin{array}{l}65.0 \\
76.8\end{array}$ & $\begin{array}{r}15.6 \\
5.6\end{array}$ \\
\hline $4 / 1988$ & $\begin{array}{l}\text { F \& S } \\
\text { Control }\end{array}$ & $\begin{array}{r}10.0 \\
7.3\end{array}$ & $\begin{array}{l}5.6 \\
0.9^{\circ}\end{array}$ & $\begin{array}{l}0.7 \mathrm{a} \\
1.3 \mathrm{a}\end{array}$ & $\begin{array}{l}0.8 \\
0.1\end{array}$ & $\begin{array}{r}17.2^{\mathrm{a}} \\
9.7^{\mathrm{a}}\end{array}$ & $\begin{array}{l}5.8 \\
7.8 \mathrm{a}\end{array}$ & $\begin{array}{l}77.0^{a} \\
82.6\end{array}$ & $\begin{array}{l}54.8 \\
38.9\end{array}$ \\
\hline $7 / 1988$ & $\begin{array}{l}\text { F \& S } \\
\text { Control }\end{array}$ & $\begin{array}{l}18.6^{b} \\
35.1^{a}\end{array}$ & $\begin{array}{l}6.3^{a} \\
3.6^{a}\end{array}$ & $\begin{array}{r}9.9^{b} \\
24.4^{a}\end{array}$ & $\begin{array}{l}0.2^{\mathrm{a}} \\
0.2^{\mathrm{a}}\end{array}$ & $\begin{array}{l}35.0^{\mathrm{b}} \\
63.3^{\mathrm{a}}\end{array}$ & $\begin{array}{l}3.2 \mathrm{a} \\
7.0 \mathrm{a}\end{array}$ & $\begin{array}{l}61.8^{a} \\
29.7^{b}\end{array}$ & $\begin{array}{l}53.0 \\
30.0\end{array}$ \\
\hline $9 / 1988$ & $\begin{array}{l}\text { F \& S } \\
\text { Control }\end{array}$ & $\begin{array}{l}17.3^{a} \\
20.8^{a}\end{array}$ & $\begin{array}{r}15.3^{\mathrm{a}} \\
5.2^{\mathrm{a}}\end{array}$ & $\begin{array}{r}8.1^{b} \\
25.7^{a}\end{array}$ & $\begin{array}{l}0^{a} \\
0^{a}\end{array}$ & $\begin{array}{l}40.7^{a} \\
51.7^{a}\end{array}$ & $\begin{array}{l}2.1^{a} \\
1.9^{a}\end{array}$ & $\begin{array}{l}57.2 \\
46.4\end{array}$ & $\begin{array}{l}59.6 \\
42.2\end{array}$ \\
\hline $4 / 1989$ & $\begin{array}{l}\text { F \& S } \\
\text { Control }\end{array}$ & $\begin{array}{r}6.3^{a} \\
12.2^{a}\end{array}$ & $\begin{array}{l}1.0^{a} \\
2.0^{a}\end{array}$ & $\begin{array}{l}1.1^{a} \\
2.0^{a}\end{array}$ & $\begin{array}{l}0^{a} \\
0^{a}\end{array}$ & $\begin{array}{r}8.4^{a} \\
16.2^{a}\end{array}$ & $\begin{array}{l}3.0^{a} \\
6.6 \mathrm{a}\end{array}$ & $\begin{array}{l}88.6 \\
77.2^{a}\end{array}$ & $\begin{array}{l}88.5 \\
61.1\end{array}$ \\
\hline $7 / 1989$ & $\begin{array}{l}\text { F \& S } \\
\text { Control }\end{array}$ & $\begin{array}{l}15.4^{a} \\
23.3^{a}\end{array}$ & $\begin{array}{l}4.3^{a} \\
4.0^{a}\end{array}$ & $\begin{array}{r}6.2^{b} \\
13.0^{a}\end{array}$ & $\begin{array}{l}0^{a} \\
0^{a}\end{array}$ & $\begin{array}{l}25.9 \\
40.3\end{array}$ & $\begin{array}{r}2.6^{a} \\
10.4^{a}\end{array}$ & $\begin{array}{l}71.5^{a} \\
49.2^{a}\end{array}$ & $\begin{array}{l}72.2 \\
51.1\end{array}$ \\
\hline $9 / 1989$ & $\begin{array}{l}\text { F \& S } \\
\text { Control }\end{array}$ & $\begin{array}{l}11.1^{b} \\
23.3^{a}\end{array}$ & $\begin{array}{l}2.6^{b} \\
6.9^{a}\end{array}$ & $\begin{array}{r}4.0^{b} \\
16.2^{a}\end{array}$ & $\begin{array}{l}0^{a} \\
0^{a}\end{array}$ & $\begin{array}{l}17.7^{b} \\
46.4^{a}\end{array}$ & $\begin{array}{l}0.7^{b} \\
1.0^{a}\end{array}$ & $\begin{array}{l}81.7^{a} \\
52.6^{b}\end{array}$ & $\begin{array}{l}84.1 \\
37.8\end{array}$ \\
\hline $4 / 1990$ & $\begin{array}{l}\text { F \& S } \\
\text { Control }\end{array}$ & $\begin{array}{r}8.1^{b} \\
20.0^{a}\end{array}$ & $\begin{array}{l}1.2^{a} \\
2.6^{a}\end{array}$ & $\begin{array}{l}1.7^{b} \\
8.0^{a}\end{array}$ & $\begin{array}{l}0^{a} \\
0^{a}\end{array}$ & $\begin{array}{l}11.0^{\mathrm{b}} \\
30.6^{\mathrm{a}}\end{array}$ & $\begin{array}{l}0.7^{a} \\
6.4^{a}\end{array}$ & $\begin{array}{l}88.4^{a} \\
63.0^{\circ}\end{array}$ & $\begin{array}{r}91.5 \\
100.0\end{array}$ \\
\hline
\end{tabular}

tPercent values transformed to arc sine of the square root of the percent value, expressed as a decimal fraction, to normalize values belore statistical analysis.

\$F \& $S$ = application of fertilizer and seed; Control = natural revegetation.

SAll, $n=36 ; F$ \& $S, n=27 ;$ Control, $n=9$.

tt Means for a category and collection date followed by the same letter are not significantly different $(P \leq 0.05)$ by Sidak's pairwise $t$ test. 
TABLE 3 Mean Percent Cover of All Transects by Collection Date and Closure Period

\begin{tabular}{|c|c|c|c|c|c|c|c|c|c|}
\hline \multirow[b]{2}{*}{$\begin{array}{l}\text { Collection } \\
\text { Date }\end{array}$} & \multirow[b]{2}{*}{$\begin{array}{l}\text { Closure } \\
\text { Period }\end{array}$} & \multicolumn{8}{|c|}{ Cover by Category $(\%)^{+}$} \\
\hline & & Grass & Legume & Forb & Rye & $\begin{array}{c}\text { Total } \\
\text { Vegetation }\end{array}$ & Litter & $\begin{array}{c}\text { Exposed } \\
\text { Soil }\end{array}$ & Damage \\
\hline $6 / 1987$ & All* & 0.6 & 0 & 0.3 & 0 & 0.9 & 0 & 99.1 & 100.0 \\
\hline $9 / 1987$ & $\begin{array}{l}\text { Two Weeks } \\
\text { Two Months } \\
\text { One Year }\end{array}$ & $\begin{array}{c}13.7 \text { as } \\
17.9 \text { a } \\
6.9^{b}\end{array}$ & $\begin{array}{l}3.5^{a} \\
6.3^{a} \\
3.5^{a}\end{array}$ & $\begin{array}{r}9.0 \mathrm{a} \\
11.1 \mathrm{a} \\
7.3\end{array}$ & $\begin{array}{l}1.3^{b} \\
8.3^{a} \\
3.9^{a b}\end{array}$ & $\begin{array}{l}27.4^{b} \\
43.6^{a} \\
21.6^{b}\end{array}$ & $\begin{array}{l}1.8^{a} \\
1.3^{a} \\
0.5^{a}\end{array}$ & $\begin{array}{l}70.8^{a} \\
55.1^{b} \\
77.9^{a}\end{array}$ & $\begin{array}{c}18.3 \\
0 \\
20.8\end{array}$ \\
\hline $4 / 1988$ & $\begin{array}{l}\text { Two Weeks } \\
\text { Two Months } \\
\text { One Year }\end{array}$ & $\begin{array}{r}3.7 a^{a} \\
12.3 a^{a} \\
12.2^{a}\end{array}$ & $\begin{array}{l}0.1^{b} \\
5.3^{a b} \\
7.9^{a}\end{array}$ & $\begin{array}{l}0.3 a \\
1.2^{a} \\
1.3\end{array}$ & $\begin{array}{l}0^{b} \\
0.3^{a b} \\
1.5^{a}\end{array}$ & $\begin{array}{c}4.0^{b} \\
19.1^{a b} \\
22.8^{a}\end{array}$ & $\begin{array}{l}5.5^{a b} \\
8.0^{a} \\
5.4^{b}\end{array}$ & $\begin{array}{l}90.5^{a} \\
72.9^{a b} \\
71.8^{b}\end{array}$ & $\begin{array}{l}80.0 \\
45.0 \\
27.5\end{array}$ \\
\hline $7 / 1988$ & $\begin{array}{l}\text { Two Weeks } \\
\text { Two Months } \\
\text { One Year }\end{array}$ & $\begin{array}{l}20.1^{a} \\
24.9^{a} \\
23.2^{a}\end{array}$ & $\begin{array}{r}1.0^{b} \\
2.7^{b} \\
13.2^{a}\end{array}$ & $\begin{array}{c}8.6^{b} \\
13.8^{a b} \\
18.2^{a}\end{array}$ & $\begin{array}{l}0^{b} \\
0^{b} \\
0.7^{a}\end{array}$ & $\begin{array}{l}29.7^{a} \\
41.3^{a} \\
55.2^{a}\end{array}$ & $\begin{array}{l}3.1^{b} \\
4.1^{b} \\
5.3^{a}\end{array}$ & $\begin{array}{l}67.3^{a} \\
54.6^{a} \\
39.5^{a}\end{array}$ & $\begin{array}{c}92.5 \\
49.2 \\
0\end{array}$ \\
\hline $9 / 1988$ & $\begin{array}{l}\text { Two Weeks } \\
\text { Two Months } \\
\text { One Year }\end{array}$ & $\begin{array}{l}14.7 \mathrm{a} \\
21.2 \mathrm{a} \\
18.6\end{array}$ & $\begin{array}{c}2.0^{\mathrm{b}} \\
17.3^{\mathrm{ab}} \\
19.2^{\mathrm{a}}\end{array}$ & $\begin{array}{l}12.7^{\mathrm{a}} \\
12 . \mathrm{a}^{\mathrm{a}} \\
12.6^{\mathrm{a}}\end{array}$ & $\begin{array}{l}0^{a} \\
0^{a} \\
0^{a}\end{array}$ & $\begin{array}{l}29.3^{a} \\
50.6^{a} \\
50.3^{a}\end{array}$ & $\begin{array}{l}0.8^{b} \\
2.2^{a b} \\
3.3^{a}\end{array}$ & $\begin{array}{l}69.8^{a} \\
47.3^{a} \\
46.4^{a}\end{array}$ & $\begin{array}{l}59.2 \\
45.8 \\
60.8\end{array}$ \\
\hline $4 / 1989$ & $\begin{array}{l}\text { Two Weeks } \\
\text { Two Months } \\
\text { One Year }\end{array}$ & $\begin{array}{c}12.5^{a} \\
9.3^{a b} \\
1.6^{b}\end{array}$ & $\begin{array}{l}1.4^{\mathrm{a}} \\
1.4^{\mathrm{a}} \\
0.8^{\mathrm{a}}\end{array}$ & $\begin{array}{l}2.0^{a} \\
1.6^{a} \\
0.4^{a}\end{array}$ & $\begin{array}{l}0^{a} \\
0^{a} \\
0^{a}\end{array}$ & $\begin{array}{r}15.9^{a} \\
12.3^{a} \\
2.8^{a}\end{array}$ & $\begin{array}{l}5.7^{a} \\
5.5^{a} \\
0.6^{b}\end{array}$ & $\begin{array}{l}78.4^{a} \\
82.3^{a} \\
96.6^{a}\end{array}$ & $\begin{array}{l}70.0 \\
75.8 \\
99.2\end{array}$ \\
\hline $7 / 1989$ & $\begin{array}{l}\text { Two Weeks } \\
\text { Two Months } \\
\text { One Year }\end{array}$ & $\begin{array}{r}22.1^{a} \\
22.8^{a} \\
7.2^{a}\end{array}$ & $\begin{array}{l}8.3^{a} \\
2.3^{a} \\
2.0^{a}\end{array}$ & $\begin{array}{r}9.1^{a b} \\
13.0^{a} \\
1.7^{b}\end{array}$ & $\begin{array}{l}0^{a} \\
0^{a} \\
0^{a}\end{array}$ & $\begin{array}{l}39.55^{a} \\
38.1 a^{a} \\
10.8\end{array}$ & $\begin{array}{l}5.7^{a} \\
6.3^{a} \\
1.8^{a}\end{array}$ & $\begin{array}{l}54.8^{a} \\
55.6^{a} \\
87.4^{a}\end{array}$ & $\begin{array}{l}56.7 \\
47.5 \\
96.7\end{array}$ \\
\hline $9 / 1989$ & $\begin{array}{l}\text { Two Weeks } \\
\text { Two Months } \\
\text { One Year }\end{array}$ & $\begin{array}{c}26.3^{a} \\
13.9^{a b} \\
2.2^{b}\end{array}$ & $\begin{array}{l}8.5^{a} \\
2.3^{a} \\
0.2^{a}\end{array}$ & $\begin{array}{r}11.8^{a} \\
8.6^{a} \\
0.8^{b}\end{array}$ & $\begin{array}{l}0^{a} \\
0^{a} \\
0^{a}\end{array}$ & $\begin{array}{r}46.7^{a} \\
24.8^{a} \\
3.2^{b}\end{array}$ & $\begin{array}{l}1.7^{a} \\
0.5^{b} \\
0.1^{b}\end{array}$ & $\begin{array}{l}51.7^{b} \\
74.8^{b} \\
96.8^{a}\end{array}$ & $\begin{array}{r}45.8 \\
71.7 \\
100.0\end{array}$ \\
\hline $4 / 1990$ & $\begin{array}{l}\text { Two Weeks } \\
\text { Two Months } \\
\text { One Year }\end{array}$ & $\begin{array}{l}21.0^{a} \\
9.6^{a b} \\
2.7^{b}\end{array}$ & $\begin{array}{l}4.5^{a} \\
0.1^{b} \\
0^{b}\end{array}$ & $\begin{array}{l}6.8^{a} \\
2.5^{a b} \\
0.4^{b}\end{array}$ & $\begin{array}{l}0^{a} \\
0 a \\
0 a\end{array}$ & $\begin{array}{c}32.3^{a} \\
12.2^{a b} \\
3.1^{b}\end{array}$ & $\begin{array}{l}2.3^{a} \\
3.3^{a} \\
0.8^{b}\end{array}$ & $\begin{array}{l}65.4^{\mathrm{b}} \\
84.6^{\mathrm{ab}} \\
96.1^{\mathrm{a}}\end{array}$ & $\begin{array}{r}80.8 \\
100.0 \\
100.0\end{array}$ \\
\hline
\end{tabular}

tPercent values transformed to arc sine of the square root of the percent value, expressed as a decimal fraction, to normalize values before statistical analysis.

tAll, $n=36 ; n=12$ for all other closure periods.

SMuans for a category and collection date followed by the same letter are not significantly different (P $\leq 0.05)$ by Sióak's pairwise $t$ test. 
Inspection of the data in Table 2 indicates no statistically significant differences between the amount of grass, legume, and forb cover and amendment options for any of the eight data collection dates. Nevertheless, several general trends related to amendment options may be iliustrated by these data. During the initial year of monitoring, the amounts and proportions of grass and legumes on the fertilized and seeded areas are generally higher than those in the control or natural revegetation areas. The amount (and proportion) of forb cover on the control area was higher than that in the fertilized and seeded area. This increase in the percent grass and legume cover resulted in an increase in the percent total vegetative cover and a reduction in the percent exposed soil during this period. The decrease in the percent exposed soil and the higher proportion of grasses in the total vegetative cover reduced the potential for soil erosion. The marked decrease in the percent total vegetative cover and the general decline in the proportion of grasses and legumes in the vegetative stand after only one growing season was probably attributable to the higher percent damage to the fertilized and seeded area in comparison with the control area. Therefore, on the basis of the data, it can be concluded that regular fertilization anis seeding will be necessary to maintain adequate grass, legume, and total vegetative cover for effective erosion control.

Data given in Table 2 slso indicate that as military traffic increases (as indicaied by the mean percent damage), the percent total vegetative cover decreased while the percent exposed soil iricreased. Moreover, all 36 transects had nearly 100\% exposed soil during June 19.87 (at the start of the study), and during the final monitoring session in April 1990, both option areas had some vegetative cover. The data indicate that some vegetation, including a large proportion of grass and legumes in some cases, survived on all the transects after almost three years of military traffic. The data also indicate that vegetation damage is cumulative, and the complete destruction of all vegetative cover requires several years of military training activities.

Data listed in Table 2 also show that a low percentage of cereal rye cover was present in the fertilized and seeded areas during the September 1987 collection period. The decrease in the percent cereal rye cover in the spring of 1988 and the disappearance of cereal rye by the fall of 1988 indicate that cereal rye was destroyed by traffic and therefore did not reseed. Cereal rye was included in the seed mixture to provide quick vegetative cover for immediate erosion control while perennial species became established. These findings suggest that cereal rye is not well suited for this purpose, and other quick-cover species should be considered. The use of perennial ryegrass (Lolium perenne) or annual ryegrass (Lolium multiflorum) would also provide the intended quick vegetative cover for immediate erosion control. An additional advantage of using perennial quickcover species is that they may survive or reseed to provide additional vegetative cover in following years. The amount of quick-cover species included in the seed mixture must be carefully considered because the quick-cover species could compete with perennial species and prevent them from becoming established. Because of the potential problems associated with quick-cover species, the seeding rate should be calculated on the basis of the number of viable seeds per unit area, not seed weight per unit area.

Data given in Table 3 also indicate no statistical relationships between the amount of grass, legume, forb, or rye cover and closure period for any of the eight data collection dates. When the data from closure periods are compared, trends in those data not appear to be as defined as those 
when the data from the ameridment options are compared. One trend is apparent - the average percent damage for the three closure periods does indicate that there was a high and consistent amount of unauthorized traffic in areas that were closed. Therefore, attempts close areas during revegetation operations were ineffective.

Additional statistical analyses of the cover data were performed by using only data from transects that were not damaged by recent military traffic. The influence of military traffic was not completely eliminated by this selection process because damage may have occurred during prior data-collection efforts. The means of the ground cover categories from only undamaged transects by collection date and amendment options are listed in Table 4. These same data, grouped by closure period, are given in Table 5. Statistically significant differences among means within each cover category for each collection date and amendment option or closure period are indicated.

TABLE 4 Mean Percent Cover of Undamaged Transects by Collection Date and Amendment Option

\begin{tabular}{|c|c|c|c|c|c|c|c|c|c|}
\hline \multirow[b]{2}{*}{$\begin{array}{c}\text { Collection } \\
\text { Date }\end{array}$} & \multirow[b]{2}{*}{$\begin{array}{c}\text { Amendment } \\
\text { Option }\end{array}$} & \multirow[b]{2}{*}{$n$} & \multicolumn{7}{|c|}{ Cover by Category $(\%)^{\dagger}$} \\
\hline & & & Grass & Legume & Forb & Rye & $\begin{array}{c}\text { Total } \\
\text { Vegetation }\end{array}$ & Litter & $\begin{array}{c}\text { Exposed } \\
\text { Soil }\end{array}$ \\
\hline 9/1987 & $\begin{array}{l}\text { F \& S } \\
\text { Control }\end{array}$ & $\begin{array}{r}21 \\
8\end{array}$ & $\begin{array}{l}14.4^{\mathrm{a}} \S \\
10.9^{\mathrm{b}}\end{array}$ & $\begin{array}{l}7.0^{\mathrm{a}} \\
1.0^{\mathrm{b}}\end{array}$ & $\begin{array}{r}10.1^{\mathrm{a}} \\
9.9^{\mathrm{a}}\end{array}$ & $\begin{array}{l}6.6^{a} \\
0.1^{b}\end{array}$ & $\begin{array}{l}38.1^{a} \\
21.9^{b}\end{array}$ & $\begin{array}{l}1.1^{\mathrm{a}} \\
0.9^{\mathrm{b}}\end{array}$ & $\begin{array}{l}60.8^{b} \\
77.3^{a}\end{array}$ \\
\hline $4 / 1988$ & $\begin{array}{l}\text { F\&S } \\
\text { Control }\end{array}$ & $\begin{array}{l}8 \\
5\end{array}$ & $\begin{array}{l}21.8^{\mathrm{a}} \\
11.6^{\mathrm{b}}\end{array}$ & $\begin{array}{r}14.8^{a} \\
1.6^{b}\end{array}$ & $\begin{array}{l}1.9^{\mathrm{a}} \\
1.8^{\mathrm{a}}\end{array}$ & $\begin{array}{l}2.5^{a} \\
0^{b}\end{array}$ & $\begin{array}{l}40.9^{a} \\
15.0^{b}\end{array}$ & $\begin{array}{r}7.0^{b} \\
11.4^{a}\end{array}$ & $\begin{array}{l}52.1^{b} \\
73.6^{a}\end{array}$ \\
\hline $7 / 1988$ & $\begin{array}{l}\text { Fas } \\
\text { Control }\end{array}$ & $\begin{array}{r}12 \\
6\end{array}$ & $\begin{array}{l}34.2^{a} \\
25.2^{a}\end{array}$ & $\begin{array}{r}13.5^{\mathrm{a}} \\
3.8^{\mathrm{a}}\end{array}$ & $\begin{array}{l}18.8^{\mathrm{a}} \\
26.2^{\mathrm{a}}\end{array}$ & $\begin{array}{l}0.5^{a} \\
0.3^{a}\end{array}$ & $\begin{array}{l}66.9^{a} \\
55.5^{a}\end{array}$ & $\begin{array}{l}5.0^{\mathrm{a}} \\
8.5^{\mathrm{a}}\end{array}$ & $\begin{array}{l}28.1^{a} \\
36.0^{a}\end{array}$ \\
\hline 9/1989 & $\begin{array}{l}\text { F\&S } \\
\text { Control }\end{array}$ & $\begin{array}{l}3 \\
5\end{array}$ & $\begin{array}{l}43.0^{a} \\
29.2^{a}\end{array}$ & $\begin{array}{r}28.7^{a} \\
8.2^{b}\end{array}$ & $\begin{array}{r}7.0^{\mathrm{b}} \\
33.0^{\mathrm{a}}\end{array}$ & $\begin{array}{l}0^{a} \\
0^{a}\end{array}$ & $\begin{array}{l}78.7^{a} \\
70.4^{a}\end{array}$ & $\begin{array}{l}1.0^{b} \\
2.8^{a}\end{array}$ & $\begin{array}{l}20.3^{b} \\
26.8^{2}\end{array}$ \\
\hline $4 / 1989$ & $\begin{array}{l}\text { F\&S } \\
\text { Control }\end{array}$ & $\begin{array}{l}3 \\
2\end{array}$ & $\begin{array}{l}33.0^{a} \\
29.0^{\circ}\end{array}$ & $\begin{array}{l}4.0^{\mathrm{a}} \\
5.0^{\mathrm{a}}\end{array}$ & $\begin{array}{l}5.0^{\mathrm{a}} \\
2.5^{\mathrm{a}}\end{array}$ & $\begin{array}{l}0^{2} \\
0^{a}\end{array}$ & $\begin{array}{l}42.0^{a} \\
36.5^{a}\end{array}$ & $\begin{array}{l}14.0^{\mathrm{a}} \\
16.5^{\mathrm{a}}\end{array}$ & $\begin{array}{l}44.0^{\mathrm{a}} \\
47.0^{\mathrm{a}}\end{array}$ \\
\hline $7 / 1980$ & $\begin{array}{l}\text { F\&S } \\
\text { Control }\end{array}$ & $\begin{array}{l}6 \\
3\end{array}$ & $\begin{array}{l}44.7^{a} \\
39.7^{a}\end{array}$ & $\begin{array}{r}10.2^{\mathrm{a}} \\
6.7^{\mathrm{a}}\end{array}$ & $\begin{array}{l}22.2^{\mathrm{a}} \\
17.0^{\mathrm{a}}\end{array}$ & $\begin{array}{l}0^{2} \\
0^{2}\end{array}$ & $\begin{array}{l}77.0^{\mathrm{a}} \\
63.3^{\mathrm{a}}\end{array}$ & $\begin{array}{r}5.7^{a} \\
20.7^{a}\end{array}$ & $\begin{array}{c}17.3^{\mathrm{a}} \\
16.0^{\mathrm{a}}\end{array}$ \\
\hline $9 / 1989$ & $\begin{array}{l}\text { F\&S } \\
\text { Control }\end{array}$ & $\begin{array}{l}3 \\
5\end{array}$ & $\begin{array}{l}45.0^{\mathrm{a}} \\
38.6^{\mathrm{a}}\end{array}$ & $\begin{array}{l}14.3^{a} \\
10.0^{2}\end{array}$ & $\begin{array}{l}22.0^{a} \\
22.4^{a}\end{array}$ & $\begin{array}{l}0^{2} \\
0^{2}\end{array}$ & $\begin{array}{l}81.3^{\mathrm{a}} \\
71.0^{\mathrm{a}}\end{array}$ & $\begin{array}{l}4.3^{\mathrm{a}} \\
1.6^{\mathrm{a}}\end{array}$ & $\begin{array}{l}14.3^{b} \\
27.4^{a}\end{array}$ \\
\hline
\end{tabular}

tFercent values transformed to arc sine of the square root of the percent value, expressed as a decimal fraction, to normalize values before statistical analysis.

tF \& $S$ = application of fertilizer and seed; Control = natural revegetation.

SMeans for a category and collection date followed by the same letter are not significantly different $(P \leq 0.05)$ by Sidak's pairwise $t$ test. 
TABLE 5 N. zan Percent Cover of Undamaged Transects by Collection Date and Closure Period

\begin{tabular}{|c|c|c|c|c|c|c|c|c|c|}
\hline \multirow[b]{2}{*}{$\begin{array}{l}\text { Collection } \\
\text { Date }\end{array}$} & \multirow[b]{2}{*}{$\begin{array}{l}\text { Closure } \\
\text { Period }\end{array}$} & \multirow[b]{2}{*}{$n$} & \multicolumn{7}{|c|}{ Cover by Category $(\%)^{\dagger}$} \\
\hline & & & Grass & Logume & Forb & Rye & $\begin{array}{c}\text { Total } \\
\text { Vegetation }\end{array}$ & Litter & $\begin{array}{c}\text { Exposed } \\
\text { Soil }\end{array}$ \\
\hline \multirow[t]{3}{*}{$9 / 1987$} & Week & 8 & $11.6^{\mathrm{bs}}$ & $4.9 \mathrm{a}$ & $9.1^{a}$ & $0.3^{b}$ & $25.9^{b}$ & $1.1^{\mathrm{a}}$ & $73.0^{a}$ \\
\hline & Month & 12 & 17.9 a & $6.3^{a}$ & $11.1^{\mathrm{a}}$ & $8.3^{2}$ & $43.6^{2}$ & $1.3^{a}$ & $55.1^{\circ}$ \\
\hline & Year & 9 & $9.0^{\mathrm{b}}$ & $4.4^{\mathrm{a}}$ & $9.6^{a}$ & $4.2^{\mathrm{a}}$ & $27.2^{b}$ & $0.7^{a}$ & $72.1^{\mathrm{a}}$ \\
\hline \multirow[t]{2}{*}{$4 / 1988$} & Month & 5 & $23.0 *$ & $7.8 \AA$ & $2.0^{\circ}$ & $0.6^{2}$ & $33.4^{\mathrm{a}}$ & $11.8^{\mathrm{a}}$ & $54.8^{a}$ \\
\hline & Year & 8 & $14.6^{\star}$ & $10.9 \times$ & $1.8^{a}$ & $2.1^{a}$ & $29.4^{a}$ & $6.8^{a}$ & $63.9^{a}$ \\
\hline \multirow[t]{2}{*}{$7 / 1988$} & Month & 6 & $47.2^{\star}$ & $4.5^{2}$ & $27.3^{a}$ & $0^{a}$ & $79.0^{a}$ & $7.8^{a}$ & $13.2^{b}$ \\
\hline & Year & 12 & $23.2^{b}$ & $13.2^{a}$ & $18.2^{a}$ & $0.7^{a}$ & $55.2^{a}$ & $5.3^{\mathrm{a}}$ & $39.5^{\mathrm{a}}$ \\
\hline \multirow[t]{3}{*}{$9 / 1988$} & Weak & 1 & $28.0^{a}$ & $5.0^{\mathrm{a}}$ & $10.0^{b}$ & $0^{a}$ & $43.0^{\mathrm{b}}$ & $0.0^{a}$ & $57.0^{a}$ \\
\hline & Month & 5 & 39.8 a & $18.4^{a}$ & $23.4^{a b}$ & $0^{a}$ & $81.6^{\mathrm{a}}$ & $2.4^{\mathrm{a}}$ & $16.0^{\mathrm{ac}}$ \\
\hline & Year & 2 & $24.0^{\mathrm{a}}$ & $15.0^{\mathrm{a}}$ & $29.5^{a}$ & $0^{a}$ & $68.5^{a b}$ & $2.5^{\mathrm{a}}$ & $29.0^{b}$ \\
\hline \multirow[t]{2}{*}{$4 / 1989$} & Weok & 3 & $330 \mathrm{a}$ & $4.0^{\mathrm{a}}$ & $5.0^{2}$ & $0^{a}$ & $42.0^{\mathrm{a}}$ & $14.0^{\mathrm{a}}$ & $44.0^{\mathrm{a}}$ \\
\hline & Year & 2 & $29.0=$ & $5.0^{2}$ & $2.5^{a}$ & $0^{a}$ & $36.5 \mathrm{a}$ & $16.5^{a}$ & $47.0^{a}$ \\
\hline \multirow[t]{2}{*}{$7 / 1989$} & Week & 3 & $42.7^{a}$ & $18.3 \mathrm{a}$ & $15.7^{a}$ & $0^{a}$ & $76.7^{\mathrm{a}}$ & $6.7^{b}$ & $16.7^{a}$ \\
\hline & Month & 6 & $43.2^{a}$ & $4.3^{b}$ & $22.8^{a}$ & $0^{a}$ & $70.3^{a}$ & $12.7^{a}$ & $17.0^{a}$ \\
\hline \multirow[t]{2}{*}{$9 / 1989$} & Week & 5 & $41.4^{a}$ & $14.2^{a}$ & $21.0^{\mathrm{a}}$ & $0^{a}$ & $76.6^{a}$ & $3.0^{\mathrm{a}}$ & 20.4 \\
\hline & Month & 3 & $40.3^{a}$ & $7.3^{a}$ & $24.3^{a}$ & $0^{a}$ & $72.0^{a}$ & $2.0^{a}$ & $26.0 \mathrm{a}$ \\
\hline
\end{tabular}

\footnotetext{
tPercent values transformed to arc sine of the square root of the percent value, expressed as a decimal fraction, to normalize values before statistical analysis.

tWeek = about two weeks, Month = about two months, and Year = about one year.

\$Means for a category and collection date followed by the same letter are not significantly different (P $\leq 0.05)$ by Sidak's pairwise $t$ test.
}

The means in Table 4 show that statistically significant differences exist in the percent grass, legume, and total vegetation cover between amendment options for the first and second collection dates. The percentages of these three cover categories are significantly higher in the fertilized and seeded areas than those in the control or natural revegetation areas, and this trend in the data was observed for all collection dates. The percent forb cover on the fertilized and seeded areas is similar to that on the control areas. Therefore, the proportion of grass and legume cover in the fertilized and seeded areas is higher than that in the control areas. This higher proportion of grasses and legumes, along with the higher percent total cover, reduces the potential for soil erosion on the areas amended with fertilizer and seed. 
Although the percent grass, legume, and total vegetative cover in the undamaged fertilized and seeded areas was higher than that in the control areas for all collection dates, the percent grass and legume cover did not increase after September 1989. Damage to the transects during previous monitoring sessions probably adversely affected the percent increase in grass and legume cover. The absence of a continued increase in grass, legume, and total vegetative cover illustrates the importance of regular and, possibly, annual maintenance programs for tactical training areas.

The data given in Table 4 indicate that the percent grass, legume, and total vegetation cover is increased by broadcasting fertilizer and seed without seedbed preparation. Therefore, one potential method for a regular fertilization and seeding program could be the aerial application of these amendments. An advantage of aerial fertilization and seeding is the elimination of the influence of ground surface conditions. Aerial applications could be made quickly over relatively large areas during the appropriate season (without the problems encountered by the contractor at the MTA site).

The data presented in Table 4 demonstrate that natura. revegetation does occur, as indicated by the establishment of vegetation on previously barren areas. A comparison of the cover category means from amended areas with control areas indicates that low soil fertility or the lack of an adequate source of seed may be the limiting factors. The data also indicate that the lower proportion of grasses in the naturally established cover may not be as desirable for effective erosion control. The natural reestablishment of vegetation on previously barren areas indicates that not all vegetation is destroyed each year by military traffic.

The data given in Table 5 from only undamaged transects grouped by closure periods do not show statistical differences or trends among any of the cover categories and closure periods. These data represent only transects without apparent recent vegetation damage and do not reflect damage that occurred before the collection period. Examination of the data from individual transects indicates that all transects were subjected to traffic during one of the collection dates. Individual transect data also indicate repeated damage on the majority of the transects. Frequent and repeated damage by traffic undoubtedly influenced the results of the comparisons among closure periods. These data do indicate that the duration of closure period has little, if any, influence on the type and amount of vegetation established.

\subsection{Cost Analysis}

A third objective of the monitoring phase of the MTA project was to compare the cost of amendments and seedbed preparation options with the types and amounts of vegetation established by those options. Because the contractor failed to perform a number of the seedbed preparation operations included in the original design of the project, the value of the economic analysis given here is limited. The economic data presented here should be used only for comparison because of the wide variation in costs attributable to the local availability of materials, labor, and equipment used. All costs reflect the price paid to the contractor in 1987 and include the labor, materials, and equipment use costs for the application of the amendments, as well as contractor overhead, charges 
for supervisory personnel, mobilization and demobilization of equipment, and profit. For these reasons, the cost data provided in this report may not reflect the costs for broadcast fertilization and seeding in future projects or the costs for similar operations at other locations.

The costs of materials and operations required for fertilization and seeding at the MTA site are given in Table 6 and reflect the adjusted bid price of the contractor. The costs of fertilizer and seed include charges for transporting and storing these materials in a local warehouse prior to their use. The costs for labor and equipinent use for the fertilization and seeding operations were calculated by subtracting material costs from the bid price for each operation. Costs were originally in Deutsche marks (DM) and corverted to U.S. dollars at the 1987 rate.

Ground cover data indicate that soil fertility and a seed source are probably major factors in the establishment of vegetation at the MTA site. Although statistical differences are absent, trends in the data indicate that fertilization and seeding resulted in a higher percent grass, legume, and total vegetative cover compared with naturally revegetated areas. Fertilization and seeding also increased the proportion of grasses and legumes in the total vegetation. These trends in the data indicate that the potential for erosion would be less on the fertilized and seeded areas.

The data in Table 6 indicate that labor and equipment use account for about $90 \%$ of the total cost of fertilization and seeding. Therefore, sufficient quantities of fertilizer and seed need to be applied during initial operations to avoid needless repeated applications. The relatively high cost of (1) labor and equipment use and (2) the broadcast application of fertilizer and seed at the MTA site makes it clear that a less expensive method for applying fertilizer and seed needs to be developed. Less expensive application methods are increasingly needed because heavily used tactical training areas need regular or possibly annual applications of fertilizer and seed.

TABLE 6 Cost of Materials and Operations for Implementation of Amendments at the Project Site

\begin{tabular}{|c|c|c|}
\hline Component & DM ha-1 & $\$$ acre $^{-1+}$ \\
\hline \multicolumn{3}{|l|}{ Materials } \\
\hline Fertilizer (208 $\mathrm{kg}$ of $12-12-12$ ) & 208 & 48 \\
\hline Seed mixture $(75.5 \mathrm{~kg})$ & 215 & 50 \\
\hline \multicolumn{3}{|l|}{ Operations } \\
\hline Broadcast fertilizer & 2042 & 472 \\
\hline Broacicast seed mixture & 2035 & 471 \\
\hline $14 \%$ value-added tax & 630 & 146 \\
\hline Total & 5130 & $\overline{1186}$ \\
\hline
\end{tabular}

$+1.75 \mathrm{DM}=\$ 1.00$ and $1.00 \mathrm{ha}=2.47$ acres. 
The value of the concertina wire and the labor costs for installing, moving, and removing the concertina wire were not calculated or reported because the wire and labor were provided by DEH at HTA. Observations made during installation of the concertina wire indicate that hundreds of hours of labor were required to enclose the 13.5-ha site. Despite the expenditure of labor for installation of the concertina wire, unauthorized military activities continued over much of the site. Ground cover data from the undamaged transects at the MTA site indicate that closure periods yielded little or no benefit. Because closure periods were not effective and the amount of time and effort to close the site were significant, site closure is neither economical nor practical for regular revegetation efforts on tactical training areas. 


\section{Summary and Conclusions}

The MTA project was initiated to develop and evaluate revegetation procedures for establishing adequate vegetative ground cover so that erosion could be controlled on tactical training areas at minimal cost and with minimal distuption to training activities. The initial phase of the project involved the development of a project work plan, selection of a study site, preparation of specifications for revegetation procedures to be tested, and implementation of revegetation treatments at the study site. A matrix-plot design was developed for evaluating the 12 treatments at a 13.5-ha site located in a heavily used valley at HTA. The revegetation procedures to be tested involved amendment and seedbed preparation options that were combined with three different durations of site closure. The amendment and seedbed preparation options were (1) broadcast application of fertilizer and a seed mixture; (2) fertilization and seeding followed by harrowing; (3) leveling, ripping, fertilization, tillage, seeding and harrowing; and (4) no amendments with natural revegetation. The three closure periods selected were about two weeks, two months, and one year.

Specifications for the amendments and seedbed preparation options were prepared and a contract was awarded to a local contractor, with implementation scheduled to start in early June of 1987. Above-average and extended periods of rainfall during May and June prevented the contractor from starting amendment applications and seedbed preparation operations until the final week of June. Wet and rutted surface conditions and standing water prevented the contractor from performing the seedbed preparation operations. As a result, components of the specifications actually implemented included only six treatments - the broadcast application of the amendinents (fertilizer and seed mixture) and natural revegetation in combination with the three closure periods. This initial phase of the project was completed in early July of 1987.

The second phase of the project consisted of monitoring the types and amounts of vegetative ground cover developed on the six treatment areas at the site. Ground cover was measured on 36 permanently marked transects by using the point-intercept method each spring, summer, and fall through the spring of 1990. Data were collected in six categories: grass, legume, forb, rye, litter, and exposed soil. Recent damage to vegetation was recorded during each monitoring session, and total vegetative cover was calculated. The data were statistically analyzed to determine differences between the amended and naturally revegetated areas and among the three closure periods.

The results of the initial collection of ground cover data, made prior to application of the amendments, confirm that all the transects were nearly barren. Data from all the transects collected during the three growing seasons indicate that the percent grass, legume, and total vegetative cover was higher on the areas receiving the fertilizer and seed mixture than on tie natural revegetation areas, although natural revegetation did occur. The proportion of grass and legume cover in the wotal vegetative cover was also higher on amended areas than on the natural revegetation area. When data from only undamaged transects were analyzed, the trends in the data were the same, and the differences between in the percent grass, legumes, and totai cover were higher without thie 
influence of traffic. The data indicate that the potential for soil erosion is reduced with an application of fertilizer and seed.

Cover data indicate that cereal rye contributes a very small portion to the total vegetative cover and that the rye disappeared from the vegetative cover in short time. Rye was included in the seed mixture to provide cover during the initial growing season (for erosion control) while perennial species became established. The failure of the rye to become established and persist through one growing season indicated that other quick-cover species should be considered.

Ground cover data collected over three years of monitoring at the MTA site indicate that the amount of vegetative cover can be increased by fertilization and seeding. The data also indicate that broadcasting these amendments without seedbed preparation increases the proportion of grass and legume cover. Therefore, a regular or possibly annual maintenance program is required on heavily used tactical training areas to provide adequate ground cover for effective erosion control. The cost of applying the amendments to maintain adequate ground cover may appear high, but when the alternative of uncontrolled erosion is considered, the cost appears to be more reasonable. A small proportion of the total cost was for fertilizer and seed, indicating that a less-expensive method must be developed and tested to reduce the cost of revegetation. The hours of labor and the ineffectiveness of the wire to exclude traffic from designated closed areas, combined with the lack of a measurable response on the undamaged transects, show that closing an active tactical training site during revegetation is not economical or practical.

Ground cover data indicate that the duration of closure period (about two weeks, about two months, or one year) had no influence on the types or amounts of vegetation established. Trends attributable to closure period were not evident when data from the undamaged transects were analyzed. The closure-related findings, coupled with the expenditure of labor to close an area, suggest that effort and funds should be used for fertilization and seeding during revegetation operations, not for site closure. The ground cover data also confirm that as military traffic occurred on the site (as indicated by the increase in the average amount of damage observed on the transects), the percent total vegetative cover decreased and the percent exposed soil increased. Nevertheless, after nearly three years of monitoring, some vegetative cover was still present on all the areas. These findings indicate that damage to ground cover is cumulative and that several years of repeated traffic are necessary to destroy all ground cover. Therefore, a regular and possibly annual reseeding effort is needed on active tactical training areas.

Because the contractor was delayed and had difficulty in applying amendments (fertilizer and seed mixture) at the MTA site (and because the cost of this operation was high), new and improved methods must be developed for fertilizing and seeding training areas that are not dependent on site conditions. The results of this study do show that total vegetative cover can be increased to reduce the potential erosion on a typical training area, but the development of economical and practical methods to accomplish this task will require additional study. 


\section{Recommendations}

The fourth and final objective of the MTA project was to formulate recommendations for more effective methods of establishing ground cover to control erosion on tactical training areas at lower cost. Failure of the contractor to perform the seedbed preparation operations as specified because of ground conditions at the site and unauthorized military traffic on areas during designated closure periods compromised the design of the project. Even with these limitations, the results of the project have made it possible to formulate several recommendations.

Revegetation operations, such as fertilization and, particularly, seeding, should be implemented at a time when seasonal conditions are the most favorable for plant growth. For example, seeding operations should be planned and contract arrangements made well in advance of the prime growing season so that the seeding operations will be done during optimal seasonal temperatures and precipitation. Background information from HTA indicated that the site should have been seeded in early April or early September. The MTA site was seeded at the end of June, which was too late for optimal spring temperatures and rainfall, conditions that may have aided in the establishment of species in the seed mixture. The success or failure of a revegetation project could depend on the weather conditions that prevailed while seedlings were growing and becoming established. Because of the cost of revegetation operations, the potential success of these ventures should not be compromised by the inappropriate planning and timing of these efforts.

Cereal rye was included in the seed mixture used at the MTA site to provide quick cover for immediate erosion control. Ground cover data indicate that the rye was not well established during the initial growing season, and ground cover was not observed in the vegetative cover after the first year. For these reasons, alternative quick-cover species, such as annual or perennial ryegrass, should be considered for immediate erosion control. Seeding rates for quick-cover species should be comparatively low because these aggressive species can prevent or retard the establishment of the more permanent and durable species in the seed mixture. Because the seeds of different species vary in size and weight, the amount of seed for individual species in the mix should be calculated on the basis of the number of seeds per unit area, not on the basis of the weight of seed per unit area.

Results from the MTA project indicate that the amounts of grass, legumes, and total vegetative cover were increased by the application of fertilizer and seed, but ground cover data also indicate that natural revegetation occurred. The MTA project was not designed to separate the influence of fertilization from seeding. Additional studies should be conducted to determine if soil fertility or a seed source is the most limiting factor in the revegetation of a training area. Because soil fertility and seed sources (from the soil seed bank or adjacent areas) are site-specific conditions, these studies must be conducted on small plots at each installation before large-scale fertilization and reseeding operations are conducted.

Ground cover data show that the broadcast application of fertilizer and seed improved the establishment of vegetative ground cover without seedbed preparation operations. Cost data show 
that the fertilizer and seed accounted for about $10 \%$ of the tctal cost, while application of the amendment made up about $90 \%$ of the total cost. The cost data suggest that less expensive methods for the application of fertilizer and seed should be investigated. Surface conditions at the MTA site hampered the application of amendments. Aerial application of amendments may reduce the cost of amendment application, and this method is not affected by the surface conditions of the site.

The use of concertina wire to close the site proved to be an ineffective means to discourage military use of an area for relatively short periods. The ineffectiveness of the wire barrier, along with the amount of labor required to install and remove concertina wire, suggests that this method of site closure is not practical or economical. The results of this and other studies generally indicate that funds should be expended on the application of amendments, not on ineffective methods of site closure.

Although the design of the MTA project was altered by site conditions and military traffic, these situations are typical for revegetation operations at tactical training areas. Thus, the conclusions drawn and recommendations made as a result of the MTA project have yielded insight into (and therefore improved our understanding of) typical revegetation operations at tactical training areas. 


\section{References}

Chambers, J.E., and R.W. Brown, 1983, Methods for Vegetation Sampling and Analysis on Revegetated Mined Land, U.S. Department of Agriculture, Forest Service, Intermountain Forest and Range Experiment Station, General Technical Report INT-151, 57 pp.

Griesbach, E., 1988, Truppenübungsplatz Hohenfels Geschichte einer Landschaft, Flierl-Druck KG, Amberg, Germany.

Hoffman, L., R.E. Ries, and J.E. Gilley, 1983, Relationship of Runoff and Soil Loss to Ground Cover of Native and Reclaimed Grazing Land, Agronomy J., 75(4):599-602.

Meeuwig, R.O., 1970, Infiltration and Soil Erosion as Influenced by Vegetation and Soil in Northern Utah, J. of Range Management, 25:185-188.

Miller, R.G., Jr., 1966, Simultaneous Statistical Inference, McGraw-Hill, New York, N.Y.

Ray, A.A., ed., 1982, SAS User's Guide: Statistics, 1982 Ed., SAS (Statistical Analysis System) Institute Inc., Cary, N.C.

Wischmeier, W.H., and D.D. Smith, 1978, Predicting Rainfall Erosion Losses - A Guide to Conservation Planning, U.S. Department of Agriculture, Agriculture Handbook No. 537.

Zellmer, S.D., et al., 1991, Range 8C Rehabilitation Demonstration Project, Hohenfels Training Area, Germany: Final Report, Argonne National Laboratory Report ANL/ESD/TM-40, Argonne, III.

Zellmer, S.D., et al., 1987, Documentation of the Range $8 C$ Rehabilitation Demonstration Project at Hohenfels Training Area, West Germany, Argonne National Laboratory Report ANL/ESD/TM26, Argonne, Ill.

Zellmer, S.D., et al., 1989, Minimal Technologies Application Project: Planning and Installation, Argonne National Laboratory Report ANL/ESD/TM-25, Argonne, Ill. 

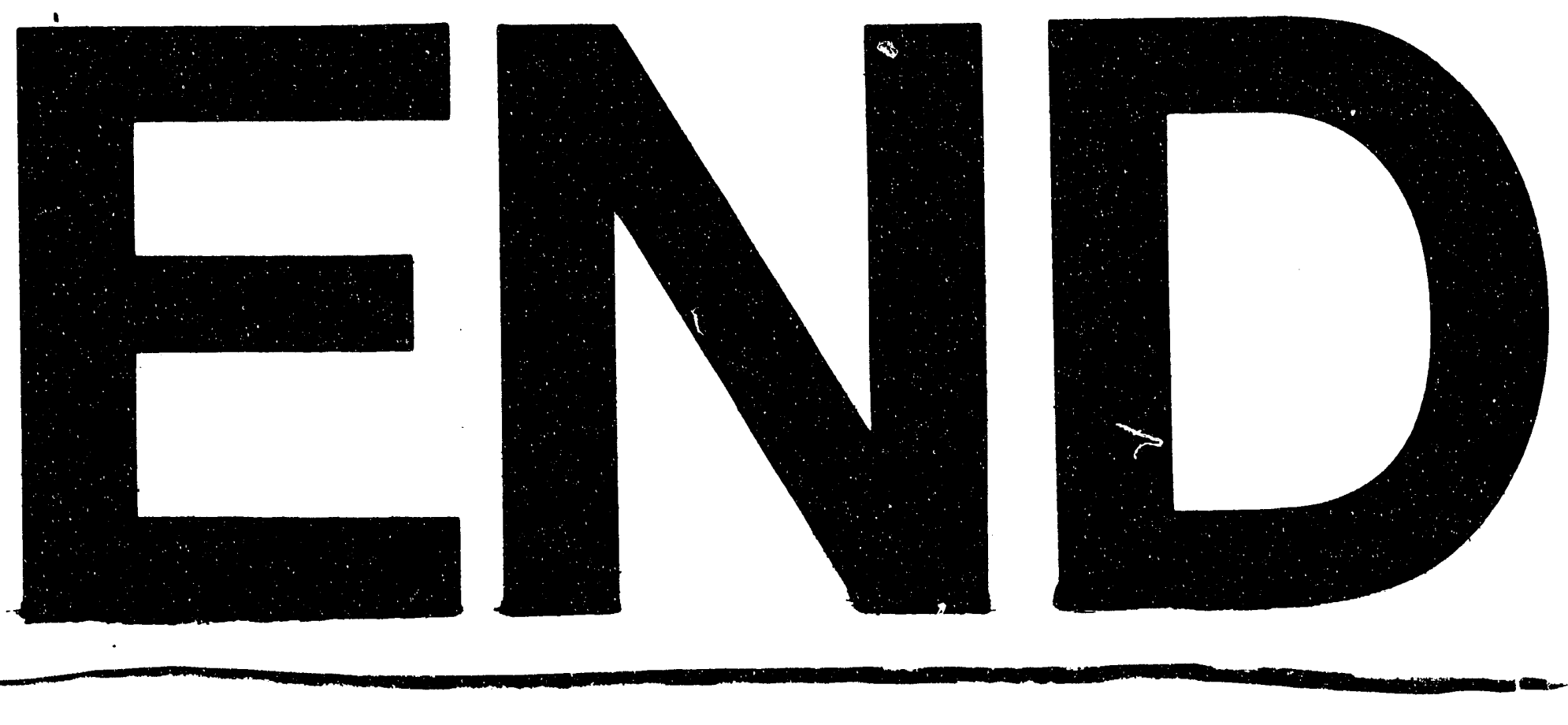
